\title{
Opening up das Schloß: Creating Room for Thinking by Combining the Territorial Cohesion Discourse and the Debate on the European Union Polity
}

\author{
B. M. Hissink Muller \\ Geography, Planning and International Development Studies, University of Amsterdam, \\ Amsterdam, The Netherlands \\ Email: b.m.hissinkmuller@uva.nl
}

Received 26 May 2016; accepted 15 August 2016; published 18 August 2016

Copyright (C) 2016 by author and Scientific Research Publishing Inc.

This work is licensed under the Creative Commons Attribution International License (CC BY). http://creativecommons.org/licenses/by/4.0/

(c) (i) Open Access

\begin{abstract}
To widen the debate about territorial cohesion, one can have a look at political science. We can namely critique the territorial cohesion discourse's exclusion of reasoning about the political by showing the relevance of the simultaneous debate on the European Union polity. It thereby also comes forward that the concept's power practices illustrate the bureaucratic, multi-level, polycentric, and network governance in flux that characterizes this polity. The territorial cohesion discourse might then exemplify how this opaque organization of governing leads to and is made possible by an associated form of expertise, which raises new questions on the role of social and spatial science in our society.
\end{abstract}

Keywords

Territorial Cohesion, Polity, Expertise, Discourse

\section{Introduction}

For a long time many in the European spatial planning community have wondered what the concept of territorial cohesion actually means. When you consider that they conducted much research on it (ESPON, 2006), in December 2009 "territorial cohesion" was confirmed as cohesion objective of the European Union as set in the Treaty of Lisbon (OJEC, 2008: p. 127). And some even say that territorial cohesion policy is a form of spatial planning (Faludi \& Waterhout, 2002: p. 5), and you can understand it determines much of their fate indeed.

How to cite this paper: Hissink Muller, B. M. (2016). Opening up das Schlob: Creating Room for Thinking by Combining the Territorial Cohesion Discourse and the Debate on the European Union Polity. Art and Design Review, 4, 83-112. 
Interpretations of territorial cohesion were however disputed in power struggles concentrated around one and two decades ago. As Faludi (2004b; 2009) for instance described in detail, while from the start France insisted to go with a more regional economic orientation much concerned with providing services of general interest (also in peripheral regions). The Netherlands responded by pressing for the coordination of policies, what's more in line with Germany's comprehensive planning style too, but they opposed the European Union to have such a competency, after which Hungary spoke for it. Waterhout (2007) accurately discerned interests in policy that meanwhile strained to direct territorial cohesion towards a Competitive, Balanced, or Green Europe as well. Such battles were fought but did not result in a clear victory though. In European spatial planning circles, the discussion on territorial cohesion nevertheless seems to be less prominent now.

We then wonder: when it is not clear what "territorial cohesion" stands for, how do its experts then now what they are dealing with? The underlying essay therefore reflects on territorial cohesion research (Campbell, 2005; Faludi, 2005a, 2007; ESPON, 2006) from the viewpoint or rather: lift-off point of European spatial planning (Williams, 1996; Faludi \& Waterhout, 2002; Jensen \& Richardson, 2003), thereby logically also adding to studies on Cohesion Policy (Petzold et al., 2015). The message of this essay stretches well beyond these spheres though.

To start with, territorial cohesion appears as a fuzzy policy concept (Markusen, 1999; Martin \& Sunley, 2003), concepts well known in spatial planning (Faludi, 2002b: p. 904; 2004e: p. 393; Campbell, 2005: p. 396; Roo \& Porter, 2007). Yet, even though its usage might be derived from the policy sphere (Hamez, 2005: p. 401), it is more than a fuzzy policy concept, as even academics carry out territorial cohesion research (Janssen-Jansen \& Waterhout, 2006). What brings us to territorial cohesion experts that have an authoritative claim to policy relevant knowledge as debated with epistemic communities (Haas, 1992; Sabatier, 1998; Zito, 1998; Radaelli, 1999: p. 762). However, we are not concerned with territorial cohesion's epistemic community in itself, nor emphasize the role of its expertise for decision-making. Here we instead focus on the role of decision-making for territorial cohesion expertise. This of course relates back to debates on and for evidence-based policy (Pawson, 2002; Davoudi, 2006), because when territorial cohesion expertise and thus its evidence can be questioned in that way, also the evidence-based policy that comes with it can, bringing us back to Cohesion policy and European spatial planning again.

The crux of this essay thus lays in reflecting on the link between the political and expertise in the case of territorial cohesion, thereby relating the debates mentioned above. The political then means that for collective action choices (e.g. in solutions) have to be made. It therefore also passes the governance debate (Kohler-Koch \& Eising, 1999; Hooghe \& Marks, 2001; Bache \& Flinders, 2005; Blanco et al., 2011) by looking beyond or rather: before governing according to already made decisions to highlight the decision-making for and in this action. Something which this essay also stresses in the end by pointing to gaps in our knowledge about political government that a different kind of territorial cohesion research could fill. Its point on the link between the political and expertise could however hold for other times and fields as well.

The path we will take in this essay to reflect on how territorial cohesion experts know what they are talking about consists of six steps. To create room for thinking we thereby always follow Said's (1978/2003: p. 18) call for intellectual endeavours: "Our role is to widen the field of discussion, not to set limits in accord with the prevailing authority". With that in mind we commence our walk by introducing the concept of territorial cohesion, that is, its meanings, usages, their relations, and the rules found that hypothetically demarcate this discourse $(\S 1)$. Our second step offers a glimpse on the landscape of political science for contrast, its concurrent debate on the European Union polity to be precise (mostly from the well-known 2001 Jean Monnet Working Paper Mountain or Molehill?: A Critical Appraisal of the Commission White Paper on Governance), a system which is shown to resemble das Schlo $\beta$ from Kafka's (1922/1959) thus-named book (\$2); note that the German "Schlo $\beta$ " both means "castle" and "lock", an essential ambiguity. This in order to, in the third step, specify the absence of the political in the discourse $(\S 3)$ even though its power practices showcase the polity's characteristics ( $\$ 4)$, as we will see while taking the fourth step. A paradox which becomes logical for us when we see in step five how the current conceptualisation of territorial cohesion correlates with the organisation of our political order ( $(5)$. The sinister linkage between power and knowledge thus portrayed finally leads us to consider a double politicisation: how an inclusion of the political in the concept's discourse calls for territorial cohesion counterknowledge $(\S 6)$. 


\section{Starting at the Territorial Cohesion Discourse from das Schloß}

\subsection{Going through Philosophical Fieldwork}

It should thus become clear first why we wonder how territorial cohesion experts know what they are talking about. Yet, the reasoning behind this question is found in the discourse analysis elsewhere (Hissink Muller, 2013). Here we just go through the main results of this "fieldwork in philosophy" (Flyvbjerg, 2001: p. 167) carried out for my $\mathrm{PhD}$, to then have these experts" discourse as our starting-point ${ }^{1}$. The question of course implies several questions. First of all, what are these experts actually talking about when they deal with territorial cohesion? In short, the Oxford Dictionary defines "cohesion" as: "the action or fact of forming a united whole", "territorial" as: "relating to the ownership of an area of land or sea". The concept is thus concerned with this forming when related to such ownership, what leaves much room for interpretation. This leads to the question of how these experts then know what they have to talk about when they talk about territorial cohesion as they do, especially because the concept is used in power practices as well. It is the relationships between these sides that really make us wonder though.

\subsection{Meaning and Knowing Territorial Cohesion}

The many meanings for territorial cohesion reflect the confusion revolving in its room for interpretation. Some here randomly chosen definitions include: economic cohesion between territories, the territorial dimension of sustainable development, equal access to Services of General (Economic) Interest, balanced regional development, horizontal coherence of European Union policies, national territorial development, and a new territorial way of thinking. You can thus read one article and/or policy document where measures are proposed to reach territorial cohesion in the sense of balanced development (CEC, 2004a: p. 27; Tatzberger, 2007), while in the other the concept is understood as coordinative action (Dutch Presidency, 2004: p. 11; Schout et al., 2006). Moreover, it is not uncommon to find two different meanings of the term in the same document (EP, 2005c: $\mathrm{p}$. 7) or to find no explicit but merely implicit meaning (Mercier, 2005a: p. 64). You could thus call it a fuzzy concept indeed.

Different kinds of meaning do seem to structure this semantic variety by grouping together definitions (i.e. descriptive, normative, policy objective, instrumental, policy coherence, spatial planning, and territorial "governmentality" 2 ones), just as the common features of all specific meanings involved outline it (i.e. the choice of territorial level and relations between levels, the exclusion of politics and tangibility). As such, this common ground of meaning validates knowledge as being territorial cohesion knowledge and frames it. When knowledge is produced but no territorial cohesion meaning given to it, it simply it not labelled as territorial cohesion knowledge, but when such meaning is given to it, it is as one of the seven above. The epistemic claims involved almost only appear in the form of descriptions, norms, and policy objectives though (e.g. a layer approach, equal opportunities, a policy hyper-cube respectively), and even then often by referring to combinations of existing information as being territorial cohesion knowledge, while facts beyond policy "facts" (e.g. territorial cohesion exists as this policy objective) are lacking. You could then easily criticise territorial cohesion meaning and knowledge, for the randomness of choosing a particular meaning over many others for instance. We are however more concerned with their.

\subsection{Using the Concept}

The limits of territorial cohesion meaning and knowledge relate to the ways in which the concept is used. Although it is used for many issues, some concentrations appear. Its agenda seems to be mostly set by issues of balance, services, territorial specificities, coordination, and the territorial dimension; you could perhaps already recognise similarities with its meanings. Territorial cohesion, and thus these issues, then plays a role in adding to European Union competency, promoting European spatial planning, the substantive expansion of Cohesion policy, and the channeling of European funding. The joined push by several mostly French regional organisations (i.e. the Association Européenne des Elus de Montagne, Conference of Peripheral Maritime Regions, EUROMONTANA) to get the concept in the constitutional treaty (AEM et al., undated) for example promoted a terri-

\footnotetext{
${ }^{1}$ Much of the text comes from the summary of my PhD-thesis (Hissink Muller, 2013).

${ }^{2}$ The usage of this term is not the focus here, but its explanation can be found in Foucault (1981).
} 
torial cohesion competency for the European Union, and by treating it elaborately for the first time the Second Cohesion Report's (CEC, 2001a) added it as an issue on the Cohesion policy agenda to be reckoned with, for the European Commission's Directorate General for regional policy at least. When the concept is used in one of these areas of action, it is therefore charged with interests, which of course pick their issues.

Moreover, the concept thereby links these areas of action as well. For instance, although the European Union does not have a competency for spatial planning officially seen, territorial cohesion policy could practically entail just that. And it could then add concerns to established Cohesion policy from European spatial planning, leading to another distribution of European Funds. Each position taken under the flag of territorial cohesion, with each issue, can thus "mobilise bias" (Schattschneider, 1960: p. 71; Lukes, 1974: p. 16) in these transformations of power relations. The concept does so with minor conflicts, which are too numerous to mention here (see below though) ${ }^{3}$, in which each position is contested in one way or another. Each usage of it charged with interest runs against other interests, which can however use the concept for that as well, by using it for another issue for instance. Without a perspectival viewpoint to start from (e.g. a national government), the concept's usage can then only be ordered in a more abstract manner. That is to say, territorial cohesion stands for a battlefield forming a corridor between these areas of action, and for the rest the concept's power practices show a systematic uncertainty (e.g. on what to decide?). Yet, our question is how this usage then relates to territorial cohesion meaning and knowledge.

\subsection{Weaving Territorial Cohesion Discourse}

The point is that almost all the concept's positions correspond to definitions of it. This would be rather straightforward if territorial cohesion had one certain meaning that determines how the concept is used in politics. However, it does not only have many meanings, but they are arbitrary as well, just as the epistemic claims framed by them, moreover, both relate to willful acts in power practices. With territorial cohesion, every intellectual choice therefore always implies a political choice.

To begin with the choice of addressing it. In an interview in 2006 an officer from the European Commission's Directorate General for environment for instance responded rather intensely to the idea that it would be very interesting scientifically seen if territorial cohesion would not be used anymore after many had "jumped on its bandwagon", this by quickly stressing that the concept is simply too valuable for policies to depart with ${ }^{4}$. Yet, when territorial cohesion is addressed, there are more intellectual choices that imply political choices. Two examples of this are: 1) if the concept is used to coordinate European Union policies territorially, territorial cohesion research cannot then focus any longer on balanced development without contradicting that usage, but must at least have a more technical meaning, and 2) if a territorial cohesion knowledge presents the compete- tiveness of all regions, this could have a detrimental effect on the promotion of specific regions with the concept (e.g. peripheral or mountainous regions), given that territorial cohesion then applies to competitiveness in general rather than that of specific regions. This suggests that daily thinking links territorial cohesion meaning and knowledge and the concept's usage.

Discursive practices thus weave interdependencies between both sides, as what has been said affects what will be said. It should then come as no surprise that the concept's weave consists of many threads. How do "possibilities of articulation" that emerge from this (Foucault, 1968: p. 58; Wæver, 1998: p. 116; Diez, 2001: p. 12) then limit what is considered to be reasonable in the case of territorial cohesion?

\subsection{Demarcating the Territorial Cohesion Discourse}

Although much can be spoken of with territorial cohesion, four rules for reasoning seem to demarcate the statements within this discourse: 1) all objects can neither be political nor tangible; 2) all operations must be policy-centred in specific ways and lack reflective argumentation; 3) all concepts must be open to relate their content to that of others; and 4) all theoretical options must be adopted. In a simplified version this comes down to: when you talk about territorial cohesion, then do not mention politics, remain rather vague, do not theorise or reflect on what you are doing but just follow policies of European spatial planning and/or Cohesion policy, and always be open to link what you say to what others can say. These boundaries of territorial cohesion discourse

\footnotetext{
${ }^{3}$ You can find more details about these minor conflicts when we look at how territorial cohesion power practices showcase das $S c h l o \beta$. ${ }^{4}$ Officer from DG Environment (personal interview in Brussels, 17th of March 2006).
} 
define it as an individual entity, as a system of knowledge with associated practices. They therefore form our starting-point of what experts are talking about, when we wonder how they know where they are talking about that is.

\subsection{From Our Starting-Point Onwards to das Schlo $\beta$}

In the case of territorial cohesion we thus find ourselves in an estranging situation. To exaggerate an anecdote: you can not only follow a track on a scientific congress about territorial cohesion, listen to one professor who tells you that territorial cohesion means "this", then listen to a next professor telling you it means "that" (or not "this"), after which no argument follows and both professors leave to continue with their own research. No, meanwhile different interests also (implicitly) dispute this topic and power practices therefore make territorial cohesion statements vary in their status. Taken both together, what for evidence (e.g. for policy) can this lead to? This not so much in the sense of epistemic communities that do or do not have an authoritative claim to policy relevant knowledge, but in the sense of how any such claim can be grounded. We can thus wonder about how territorial cohesion experts can claim the expertise they need to claim for their status as experts.

Intellectually seen the concepts" meanings and knowledge are namely arbitrary, never reasoned for (e.g. why this one instead of another?) while they contradict (e.g. either territorial cohesion is an existing state of affairs or an ideal, or either policy coherence or a policy objective, but it is impossible for it to be both), nor evidenced by tangible facts. Besides, politically seen the systematic uncertainty territorial cohesion stands for leads to uncertain changes to always contested points on the agenda.

A way to get out of this situation is to go against the rules of the discourse by doing the opposite of territorial cohesion "expertise". Here we will do this by reflecting on the territorial cohesion discourse in contrast to theory (i.e. not adopting it) on the political order of the European Union in general (i.e. not policy-specific). Besides that we thereby encounter das $S c h l o \beta$, this step of course entails a critique on the territorial cohesion discourse for its exclusion of politics because it is illogical (i.e. if something is political, then it is who rules a demarcated space), but also because there was no need for it due to a lack of thought on politics.

\section{Peaking at the Contrast of Theory on the European Union Polity}

\subsection{Problematizing the European Union's Political Order}

The territorial cohesion discourse can thus be specified by showing content of the political scientific thought that it excludes. An essential debate there during the territorial cohesion discourse as sketched above is about our political order. In its modern version this entails a problem that can be characterized by Brogan (1996: p. 804): after the Reformation opened the door for everybody to be his own priest and the Enlightenment made "everyone equally a king", how can "autonomous priests-kings [then] come together to form a political order"? That is, if each individual is assumed to be free to think and do what he wants, how to reason for collective bonds? We then need to cut off the King's head in political theory (Foucault, 1981: p. 88-89) ${ }^{5}$ to understand how we are ruled from das Schlo $\beta$ which was his today. We namely cannot conceptualise today's political order with an old vocabulary that describes vanished politics (e.g. the hierarchy of sovereignty). A problem which echo's loudly in the European Union, since for long we were without "models of the European polity which given a realistic analytical image of [it]" (Jachtenfuchs, 1997: p.11). How to deal with this?

\subsection{Defining Polity and the European Union Catch}

Our topic of conversation should then not so much be politics, because we should consider the government of all in a more structural way. Basically this is about the order in which politics is performed, the political structure, in a word: "polity" (Wind, 2001). Although polity can be characterised by the "autonomy in making and implementing collective decisions" (Schmitter, 2001), this begs the question of who this "auto-" (i.e. self) refers to. When Jessop (2000: p. 349) broadly defines political systems as "all those activities, organizations and institutions organized around (or at least involved in) making collectively binding decisions for an imagined political

\footnotetext{
${ }^{5}$ Note that the focus of Foucault's work underlines this by showing the power at work in, for instance, psychiatry (Foucault, 2006) or prisons (Foucault, 1977), that is, in other realms than the politics proper we are interested in. Still, his work is open to our focus on polity, as shown by his interest in the intertwinement of the government of self, others, and, our topic, all (Foucault, 1978).
} 
community”6 our shaky ground for making collective decisions (after the King left the stage) plainly comes forward-of which the European Union is a hyperbole.

Although "polity" is often defined as the organisation of the state, especially in case of the European Union we should look beyond "the state as the one and only blueprint for the political organisation of a society" (Kohler-Koch, 2001) instead of merely holding that its polity falls short of being one (Wind, 2001). Yet, the debate on this polity could be the most contentious and inconclusive (Walker, 2001), because it has not yet acquired its definitive institutional configuration (i.e. in territorial scale, functional scope, or political authority) (Schmitter, 2000: p. 2). That is to say, it is a new but large-scale "polity in formation" (Schmitter, 2001). No wonder this leads to an incoherent polity in institutional terms (Carporaso \& Stone Sweet, 2001: p. 228; Olsen, 2002: p. 931), or that it for now merely has degrees of polity-ness (Walker, 2001). The grounds for making collective decisions in European Union are not only shaky due to it newness though.

The catch namely lies in the European Union's related lack of both a settled template of political authority and a "thick" cultural identity (Walker, 2001). Yet, although one could call the involved decision making "slow, inefficient, secretive, biased, technocratic, and certainly not democratic, the "system" is not manifestly in crisis" (Schmitter, 2000: p. 75). How to characterise the European Union polity then?

\subsection{Unfolding the European Union Polity as das Schlo $\beta$}

In Kafka's (1922/1959) Das Schlo $\beta$ the narrator K. arrives in a village and the book tells how he "struggles to gain access to the mysterious authorities of a castle who govern the village for unknown reasons" " It is not a sovereign that reigns from this castle $(S c h l o \beta)$, but a bureaucracy that operates from it. "The villagers hold the officials and the castle in high regard, even though they do not appear to know what the officials do. The actions of the officials are never explained", and the reasons the villagers give for them contradict, an ambiguity which is not hid, but praised by the villagers as another action of an official ${ }^{8}$. Much of territorial cohesion and the European Union returns in this synopsis.

Territorial cohesion meanings and knowledge for instance contradict while they are endorsed as expertise, and the systematic uncertainty of the concept's power practices supports that we do not know what is done. Below it is therefore argued for that the territorial cohesion discourse comes from das Schloß. This castle could then represent the European polity, first of all because no sovereign reigns it there. Yet, Kafka does not simply portray a castle with a bureaucracy in it, a structure which can be seen from the outside, as in Das Schlo $\beta$ villagers operate as agencies for the officials and vice versa too. This leads to the problem of distinguishing the in- and outside. For the European Union polity, Pedersen (1994) portrays this in an explosion and implosion of politics: "Explosion in the way that politics has moved out and away from the traditional representative institutions and into various new institutional settings of corporate bodies and semi-private organisations. A movement has in a way meant an ephemeralisation of political responsibility. Thus the implosion of politics, as the political spheres close in on themselves or implode in their various forms" (Pedersen, 1994). As a result the European Union polity would be a castle build without a clear (pre)conceived plan, but subsists as a complex of building- parts with various entrances, different perspectives, and no clear edge.

This is not so much a castle you associate with the hierarchical rule of a sovereign, a pyramid simply put, as it is too complex for that. Although Ruggie (1993) calls the European Union the first truly postmodern international political form, we instead follow Kafka's exposé of modernism and see the European Union polity in the form of a lock $(S c h l o \beta)$. This by following what K. could have seen on his path when he would try to gain access to the authorities of the European Union, for which he first imagines there to be a castle to enter, but steadily starts to fathom that his path more resembles a gradual disclosing of a lock.

The mechanism of das Schlo $\beta$ can therefore be unfolded into several parts, as shown below by touching upon some of its main features, that is, consecutively, its multiple levels, flux, and polycentric, network, and bureaucratic make-up. When we peak into the European Union polity this way, we will see that its inside looks like a work of Escher (especially his Convex and Concave from 1955) with its multiple levels that connect in boggling ways, leaving us in doubt about what up and down and interior and exterior is.

\footnotetext{
${ }^{6}$ I thank Dr E. Gualini for giving me a draft version of his paper for 'Multi-level Governance: Interdisciplinary Perspectives' at the Political Economy Research Centre, University of Sheffield, 28-30 of June 2001. This quote was in this paper.

${ }^{7}$ http://en.wikipedia.org/wiki/The Castle \%28novel\%29, visited on 14 October 2014.

${ }^{8}$ http://en.wikipedia.org/wiki/The Castle \%28novel\%29, visited on 14 October 2014.
} 


\subsection{Differentiating Multiple Levels}

If K. would set course to the castle of the European Union, he could see a large structure coming in his sight right away, one which is high and broad and seems to have several stories as the tiers each castle has, but differently, unlike the towers and walls he knows of. Still, there is no dispute about whether the European Union polity consists of multiple levels. To be brief, the original structure consists of a new level above the nation-state (i.e. its supranational aspects), relations between the governments of these states on the Community level are laid over this (i.e. its intergovernmental institutions), and from 1980 onwards a system of multi-level governance emerged (Hooghe \& Marks, 2001); note that "governance" compared to "government" also involves non-governmental actors and focuses on the part of a polity meant to solve problems (see the sections on the European Union's polycentric and bureaucratic nature). Debates revolve more about how to understand the dynamics between the multiple levels and which levels are included.

We could namely explain the European Union based on nation states (as in international relations), see nation states almost solely as parts of the European Union (as in comparative politics), or see both as ill-suited to deal with its multi-level interactions (Scharpf, 2000: p. 5) ${ }^{9}$. A part of this refusal lays in that the regional, or even metropolitan (Le Galès, 2002), level could be included in the polity as well, as this breaks the dualism of European Union-nation states (e.g. regions belong to the European Union too). Eser \& Konstadakopulos (2000) for instance see two asymmetrical power shifts, one (incrementally) from the national level towards the European Union (e.g. the policy process) and the other to regional levels (e.g. decentralisation of decision- making). Still, the polity does not follow the old-fashioned hierarchical ordering when a level is added, as there is no common sovereign of nation-states ruling over them with a transnational administration implementing its will (Joerges, 2001). Walker (2001) therefore talks about a post-state political order, a relational-polity that depends upon the political authority and identity claims of other institutions (e.g. states, regions). What already brings us to its polycentric and network nature (see below). For now it should be clear though that the European Union polity always implies more than one level, i.e. das Schlo $\beta$ has multiple layers.

\subsection{Grasping Flux}

When K. would approach this castle he has in sight closer, he could soon notice that segments of the large multiple layered structure are budging, stirring, shifting, for him the whole building seems to be moving. Besides multiple levels, the make-up of the European polity namely always comes with the paradox of constant change too. We can therefore join seemingly contradicting positions on it. Where Kohler-Koch (2001) for instance envisions the European Union as a permanent type of polity, Marks et al. (1996: p. 342) see European integration as a polity creating process. When we look closer, these contradicting positions already fit. The permanence is namely of a polity partly ruled from the centre (i.e. a unitary system) and partly with dispersed rule (i.e. a compound system) (Kohler-Koch, 2001), and in the creation process "authority and policy-making influence are shared across multiple levels of government" (Marks et al., 1996: p. 342) ${ }^{10}$. Yet, even if we consider the sharing of rule in European integration as suiting the compound part of the European Union polity, how can it both be permanent and in creation?

We can unravel this paradox with help from Mamadouh (2001: p. 424), as she explains that by transferring only small and detailed packages of tasks and competencies to supranational institutions in one go, the European Union is more of an integrative mechanism than an integrated entity. The polity is thus a mechanism of permanent creation, what returns in studies on its transformation (Cowles et al., 2001), institutionalisation (Stone Sweet et al., 2001), and europeanization (Featherstone \& Radaelli, 2003). Note that this mechanism (until now) has only one direction: more European Union. Nonetheless, within it "competencies, policy-making methods and policies are in a state of flux" (Bachtler \& Polverari, 2007). What is more, the European Union polity is not only a growing structure in which policy is made (in flux), but a mechanism in which "public policy has dynamic effects on political structures" (Radaelli, 2000: p. 7, p. 9). When we have a look at its other main features below, we should therefore keep in mind that they are not part of a static entity, but of an integrative mechanism in which policies and structures mutually influence each other, i.e. das multiple-layered Schlo $\beta$ has in-built development.

\footnotetext{
${ }^{9}$ I thank Dr E. Gualini for giving me a draft version of his paper for "Multi-level Governance: Interdisciplinary Perspectives" at the Political Economy Research Centre, University of Sheffield, 28-30 of June 2001.

${ }^{10}$ I thank Dr E. Gualini for giving me a draft version of his paper for "Multi-level Governance: Interdisciplinary Perspectives" at the Political Economy Research Centre, University of Sheffield, 28-30 of June 2001.
} 


\subsection{Puzzling over Polycentrism}

K. might already find the castle of the European Union a strange one indeed. He could be perplexed by the ongoing construction which results in an instable structure, but that its multiple layers are strangely enough not hierarchically arranged as tiers can puzzle him even more. If $\mathrm{K}$. would further inspect these layers, he can already suspect that, although he is close to what he is looking for, it is not so much a castle he is dealing with. Fortunately, the polycentric make-up of the European Union polity leads to accounts of it that fit as pieces of a puzzle.

As its rule is partly unitary and partly compound, the polity at least has more than one centre. We dissect this below along a vertical axis with levels and a horizontal axis with governance. That its multiple levels already lead to a poly-centric make-up then comes forward when Schmitter (2001) calls the European Union a non-national and non-state polity. He can do so, because it "is based on an altogether more diffuse, anarchic and unaccountable system of power in which no single member state or national culture is dominant or controls the direction of the [European Union] and its machinery" (Shore, 2000). The vertical axis of decision-making is thereby stretched into "a system of continuous negotiation among nested governments at several territorial tiers" (Marks, 1993: p. 392; Böhme et al., 2004: p. 1182). We could already say that the more responsibility is shared, the harder to find accountability. Yet, how to solve this polycentric puzzle of non-hierarchical nestedness?

Usually nestedness comes with several territorial units fitting into a larger territorial unit (e.g. regions into a nation-state), whereby these units are fixed and so is their division of labour concerning policies (i.e. functional competencies), this is the archetypical state (Schmitter, 1996; Mamadouh, 2001: p. 422; Ansell, 2004: p. 227; Hooghe \& Marks, 2005: p. 217). Yet, these territorial entities and functional competencies can also vary. The well-known "confederation" for instance (e.g. a trade union) is "a loose arrangement in which territorial units may enter or exit at will, but where functional competencies are rigorously fixed" (Hooghe \& Marks, 2005: p. 217). Schmitter (1996) then sees two other ideal types of polity offering "a better description of the emerging system of governance in Europe" (Mamadouh, 2001: p. 422). This is where a "fixed number of national authorities cooperate on a variety of functional tasks" in different ways (i.e. consortio), or the territorial units doing so (on the multiple levels) even vary as well (i.e. condominio) (Hooghe \& Marks, 2005: p. 217). The European Union polity today thus harbours the possibility for each of the types, what relates to its flux as integrative mechanism. More important for us here though, is that its variation in functional competencies comes forward for its polycentric make-up. The multiple centres, due to the multiple levels, could namely be multiplied by the amount of policies, as each policy could come with own centres. This is why Walker (2001) talks about a multi-level and multi-functional polity. The polycentric puzzle of das $S c h l o \beta$ can then be solved by noticing that its amount of layers and size of rooms depend on where you are in it, as if it were an asymmetrical burr puzzle.

The "Governance School" then comes in handy, as it starts with the assumption that in the European Union "policies are made in a complex web of interaction by territorially and functionally differentiated actors" (Diez, 2001: p. 10); this complex web already brings us to the European Union's network nature (see the next section). The differentiated actors make the deliberation so dispersed (e.g. different places, moments, actors) that it is difficult to understand (Magnette, 2001). In itself governance then entails horizontal forms of interaction, negotiation, and deliberation for mutually satisfactory and binding decisions and co-operation in implementation (Schmitter, 2001). In this vein Faludi (2005a: p. 112) calls for new conceptualisations of "a reality in which Community institutions ${ }^{11}$, Member States and sub-national governments and other stakeholders operate side by side". That is to say, although the "Governance School" started on the right foot, it did not seem to march much further.

Still, although it conflates the multiple levels as we should not, this school does open the door for other

\footnotetext{
${ }^{11}$ For those of you who are unfamiliar with these official institutions, see the concise overview of the six standard institutions below. Three form the core: the Council of the European Union, the European Commission, and the European Parliament. The Council of the European Union is the supreme legislative authority. The executives of every Member State meet here (i.e. national ministers depending on the topic). The European Commission can be seen as the executive and civil service. A series of Directorates-General, headed by Commissioners (and their personal Cabinets), make up its bureaucratic structure. The European Parliament is the only legislative institution that is directly elected. This democratic institution has cross-national party groupings (Jensen \& Richardson, 2003: p. 35). Besides these three, there is the European Council, the Committee of the Regions, and the European Court of Justice. In the European Council Member States' heads of government and foreign ministers assemble in summit meetings. The Committee of the Regions acts as a source of interest-representation and decision-making structure for the wide diversity of regions (Wiehler \& Stumm, 1995: p. 247). The European Court of Justice is the highest court in the European Union in matters of European Union law and with its innovative and constituting jurisprudence transformed the European Union with a supranational legal order (Hooghe \& Marks, 2001: p. 26).
} 
stakeholders to enter the polity. We are for its polycentrism then not only speaking of the "plethora of working groups, standardization bodies, and committees of experts on which the decision-making system of the EU relies" (Pedler \& Schaefer, 1996; Joerges et al., 1997; Radaelli, 2000: p. 758). Private actors are also included (e.g. businesses, NGOs). Schmitter (2001) even holds that governance is always applied in conjunction with state and market mechanisms and the embeddedness of the participating (non-profit, semi-public, semi-voluntary) organisations in a civil society are crucial for its success. Hence, Hix (1998: p. 54) already saw "a complex web of public/private networks and quasi-autonomous executive agencies" appearing that would transform "politics and government at the European and national level into a system of multi-level, non-hierarchical, deliberative and apolitical governance" (Nugent, 1999; Faludi, 2002b: p. 902); this apolitical governance is explained below with the polity's bureaucratic nature. Said otherwise, while not-public actors are normally not considered as part of a polity, the polycentricism of the European Union's polity nonetheless covers non-governmental centres too.

When you add that some not-public actors are included but others are not, the limits of the polity become illdefined. Das multiple-layered Schlo $\beta$ with in-built development therefore not only looks like an asymmetrical burr puzzle, but it is difficult to get inside too, as it already extends outside its (expanding) bounds with officials operating as agencies for some villagers and vice versa. Although the polity can thus be open and closed as castles can be, it has another less straightforward mechanism for its lock work.

\subsection{Networking the Perspective}

$\mathrm{K}$. would nonetheless keep on trying to gain access by figuring out the complexities of the lock he is confronted with on his path to the authorities of the castle of the European Union. Yet, as the structure has multiple dispersed centres, K. considers that there might be more locks, perhaps even interrelated ones. He could namely quickly realise that a network make-up already follows logically from the interaction between the European Union's multiple centres. The large variety in territorial and functional units and strong couplings between them then lead to a large-scale polity where decision-making rules change depending on the issue at stake (i.e. variable geometry) (Jachtenfuchs, 1997: p. 5). Yet, it is even more complex than that.

To start with, governance comes into play as well, as shown above. For us it matters less here whether governance heavily relies on networks (Schout et al., 2006: p. 7) or a network mode of governance is "characterized by complex interactions between levels and sectors" (Kohler-Koch \& Eising, 1999; Hooghe \& Marks, 2001; Olsen, 2002: p. 941). Either way, the dissemination of this mode namely characterises Europeanisation (Kohler-Koch, 1999; Hooghe \& Marks, 2001; Olsen, 2002: p. 941). The polity's network nature and flux thus join into growth as networking as well. As the territorially and functionally differentiated centres are installed in the polity, when they are networked together thus, this implies "simultaneous processes of change and a pattern of mutual adaptation among co-evolving institutions" (Olsen, 2002: p. 941). In order to understand these dynamics, Olsen (2002: p. 941) deems it "likely that we will need a basic framework allowing several different types" of these developments.

Then again, in a perspectival manner we can understand the pattern of these developments in the network more thorough than in such a top-down way. Héritier (1999) elucidates this by showing how in the unclear complexity of the European Union polity each policy area offers own opportunities to evade obstacles to decision-making. These are needed, because its polycentric make-up comes with many veto positions and possibilities, what easily leads to gridlock, stalemate, and joint decision traps (Héritier, 1999; Scharpf, 2001). Yet, notwithstanding the inherent ambiguity of who decides, due to the decision-making of consensus, and the structural creative use of rules, due to the dynamics of diversity, the polity is an active and aggressive decision-maker, what leads to the institutional change and policy movement mentioned above (Héritier, 1999). Not only who decides (e.g. vetoes) what and which rules to use then depend on the policy and perspective taken, the opportunities for evasion of these decisions and rules do so too.

Although the institutional geometry differs per policy area and there are many opportunities for evasion, they have commonalities. Héritier (1999) for instance names the creative usage of institutional canals and escape routes. Think for these canals about the windows of opportunity opened by putting institutional reform on the agenda, expanding a policy area by changing a decision-making rule, shifting an issue to another institutional context, or network-building during one decision-making process for another decision, and think for these escape routes about informal strategies such as adding issues to a decision to compensate initial losers (i.e. pack- 
age deal, issue-linkage), policies of stealth by shying away from public debate, or subterfuge by formulating multi-interpretable policy that leads to specific decisions on lower levels and according to interest (Héritier, 1999). These commonalities merely show the widespread room for manoeuvre instead of a framework for it though.

Still, this does portray that the network make-up of das Schlo $\beta$ is even more complex than we previously could have seen, as its centres can be connected in multiple ways. That is to say, the castle has countless corridors on levels, stairs between them, doors of rooms, and paths in- and outwards, but these change continuously and are not open for everyone. It is locked likewise, with countless engaged cogwheels on layers, bands between them, connected springs of hasps, and long worm screws in- and outwards, but these transform continuously and are not moveable for everyone either.

\subsection{Distinguishing the Bureaucracy}

$\mathrm{K}$. could be baffled about this highly complex and always modifying lock, especially when he notes that it does not so much simply lock the castle of the European Union, but that it is much larger and more encompassing, extending over the whole castle he was looking for, moreover, that this lock actually seems to be the castle or rather: the construction. If it is a lock, then a very strange one indeed. Yet, although this description of the European Union polity might seem unusual, all the features shown above (i.e. multi-level, flux, polycentric, network) can be seen as part of a common routine, its bureaucratic make-up that is.

The bureaucracy comes with us as an artefact from the administrative state (Torgerson, 1986: p. 40). Perhaps Amy (1984: p. 580) in this respect holds that "[b] ureaucracies are inherently and strongly hierarchical institutions which put an emphasis on consensus and following orders" (e.g. of ongoing programmes and approved policies). Simply put, bureaucrats traditionally implemented the political decisions taken, as much and as efficiently as possible, and thus technically solved problems instead of setting the priorities. Our question then is how the European Union polity keeps this emphasis while paradoxically leaving the hierarchy which came with it behind.

The answer partly lies in that from the design on European integration used the "Monnet method". To be exact, "the system of engrenage whereby networks of interest groups, organized labour and firms become involved in the making of public policy (Haas, 1958), prefigures governance by technocratic consensus" (Radaelli, 1999: p. 759). Opposing interests of course need a consensus to work together, but cannot agree on everything at once, and therefore work on specific issues or particular themes, what fits with the polycentric and network make-up described above. Radaelli (1999: p. 761) can as a consequence characterise bureaucratic politics with "fragmentation, coalition formation, bargaining, networking and negotiation in functional arenas". How is this bureaucracy controlled then?

Rometsch \& Wessels (1996) come up with a simple answer after a complicated sum, that is, there is no control. When you namely add the further degree of institutional fusion (e.g. a co-operative model based on dual legitimacy of the Member States and the European Commission) to the increasing "atomisation" of the decision-making processes and higher procedural complexity with processes of institutional learning (e.g. policies influencing structure), re-equilibrium, and bureaucratisation, it is impossible to control the internal co-ordination process through a central body, moreover, this leads to a growing "in-transparency" (Rometsch \& Wessels, 1996). In brief, bureaucracy has gone wild over the multiple levels and centres in this polity without uniform or stable limits.

We can revisit a statement of Hooghe \& Marks (2001) to exemplify this. They pose that since 1992 the European Commission worked as disperser of policy and administrative manager without trying to transform the allocation of authorities within the Member States (Hooghe \& Marks, 2001). Besides that the flux of the polity entails that policies influence political structures and a dispersion of policies thus potentially transforms allocations of authority, two nuances come forward with the bureaucratic make-up described above. Not only could we question the capacity to manage the internal processes, but the European Commission is multi-functional and therefore polycentric itself as well. Moreover, also the multiple levels come in here. With the European Commission's workload increasing while European Councils prohibited it from growing in size, Schout \& Jordan (2005) namely see the governance that results from the greater cooperation with national governments as "the administrative dimension of subsidiarity" (Schout et al., 2006). Wind (2001) thinks the European Commission in 2001 nonetheless "sees itself as a central mediator between technical experts and the political system." But how 
is in the polity then mediated between technical expertise and politics when the centre to do this is itself plagued by the polycentrism networked through levels and functional arenas that lead to the in-transparency in the first place?

Following the picture above, we should look at lowers levels for such mediation, as the supranational one does not do so itself (e.g. with a hierarchy nor centre). According to Weiler (1999: p. 98), the meso-level of governance does much of the creation of the implicated norms, that is, "middle-range officials of the Community and Members States in combination with a variety of private and semi-public bodies" do so (i.e. infranationalism). This matters to us as it threatens political control by giving increased autonomy to the administrative level, what implies an increased managerialism, functionalism, and a reliance on technocratic expertise (Weiler, 1999). A consequence might then be that from the supranational level economic policies dominate (as norm) due to the combination of market-making policies and the removal of boundaries for the market (i.e. negative integration) (Scharpf, 1999). From a technocratic standpoint this could namely be legitimate because of the possibility of effective economic policy on the Community level. When we rely more on technical expertise than politics in such decisions, less if any mediation is demanded between them.

With its bureaucratic make-up the European polity thus underlines a particular form of political relationships, which is the division between experts and citizens (Torgerson, 1986: p. 40). No matter whether you see the polity more as a castle or a lock, this decisive division holds, due to which the polity can be grasped as both at the same time, as entailed by the ambiguity of $d a s S c h l o \beta$ as a certainly not clear-cut castle but also a mind-bending lock that is. However ambivalent that may be, das $S c h l o \beta$, with its hallways and doors and/or springs and hasps, is namely open for the officials that wildly run in and out inside it to tweak its working parts. Yet, while officials themselves are agencies that work for others and have citizens as their agencies too, with lacking political control, they solve problems without limits set by priorities. With the complexity and in-transparency of the European Union's multi-level, polycentric, and network polity in flux, it is thus not surprising, and expounded for territorial cohesion below, that the reasons given for bureaucrats" actions contradict.

\section{Contrasting the Territorial Cohesion Discourse with the Polity Debate}

\subsection{Excluding the Political with Territorial Cohesion While Using It}

The picture drawn of the European Union polity along K.'s path above merely touches upon a much wider and more thorough political scientific debate. Yet, we did not intend to be exhaustive, not even representative, but were purposively selective. Our treatment of the political namely allows us to understand the role the territorial cohesion practices play in the total system of relations (see below). First though, we can now contrast the territorial cohesion discourse with thought on polity, to show the peculiar way in which the former does not address the political-not to speak of das Schlo $\beta$. That is to say, how can this discourse then speak about political methods nonetheless?

In the territorial cohesion discourse there is spoken of the European Union's Community Method and Open Method of Coordination. Below the paradox is explained of how in this discourse first the latter was promoted and later the former taken as a fact, but both without actually treating the political. We first need to have a look at them separately and how they fit in the European Union polity though.

\subsection{Presenting the Community Method}

The Community Method is a way of making decisions in cases where nation states and the European Union share a competence ${ }^{12}$. Then the Member States are only authorised when the European Union does not exercise its competence (BMVBW: 2005: p. 26; Husar, 2006: p. 30). When the latter does, "the Commission makes proposals for the Council of Ministers and the European Parliament to approve before they become European law" (Faludi, 2005a: p. 111). At first sight the Community Method thus seems to be a rather straightforward way for several centres on the supranational level to work together (e.g. instead of the multi-level intergovernmental method).

\footnotetext{
${ }^{12}$ Note that although the treaty of Lisbon (OJEC, 2008) abolished the three pillar structure of which this method was a part (of the first pillar) this only made the method which was denoted thus more common in usage.
} 


\subsection{Posing the Open Method(s) of Coordination}

The Open Method of Coordination is another way of making decisions, but then in cases where the European Union does not have a competence. The European Commission put this new governance mode forward to then have a more "open, participatory, accountable, effective and coherent" exercise of power (Faludi, 2005a: p. 111). Its openness comes forward in many ways. Member States can at their own or the European Commission's initiative coordinate national policies (Schmeitz, 2005: p. 403). Their cooperation is voluntary and may also include other levels and non-governmental actors (Davoudi, 2005a: p. 438). Moreover, "[t]he method is applied in different ways to different areas, with an ad hoc procedure worked out each time" (Schmeitz, 2005: p. 403). We could therefore also speak of Open Methods of Coordination.

Still, each time the Member States collectively define policy targets as a "common concern", but their choice of policy remains a national responsibility, while objectives and indicators in the specific area respect the different (regional) contexts (Scharpf, 2001; Schmeitz, 2005: p. 403). On the basis of (periodic) national reports, (multilateral) surveys, peer review, deliberation, and benchmarking, they then exchange information and best practices to further agree on objectives and to promote innovative approaches that could lead to recommendations or guidelines (Scharpf, 2001; Schmeitz, 2005: p. 403; Davoudi, 2005a: p. 438; Faludi, 2005a: p. 112). The Open Method of Coordination would thus entail a further integration which tolerates diversity and initiates learning in a decentral way (Davoudi, 2005a: p. 438; Faludi, 2005a: p. 112). The European Union then, to follow Gualini (2008), functions more as "a platform for transnational policy transfer rather than as a system of supranational regulation" (Servillo, 2010: p. 400).

Although the Open Method of Coordination might do so with its "softer" mode of governing (Begg et al., 2001; Davoudi, 2005a: p. 438), it implies more than simply "learning through monitoring" (Scharpf, 2001). Its coordination namely comes with the naming and shaming of those that do not function properly (e.g. lag, negatively influence others, use strategies that would be self-defeating if everybody did adopt them) (Scharpf, 2001; Davoudi, 2005a: p. 438). Making the platform not only the place "where shared objectives are defined", but also "the monitoring institution that assesses national behaviour" (Servillo, 2010: p. 400). Such practices might be needed for effective decision-making with a subtle and diffused balance of power between the actors (Davoudi, 2005a: p. 438). As the Open Method of Coordination also includes a "diverse range of governmental and nongovernmental stakeholders at multiple spatial scales, it can be seen as an example of multi-level-governance" (Davoudi, 2005a: p. 438). In this respect, this method fits the European Union polity well at first sight.

\subsection{Fitting Both Methods in the European Union Polity}

The Open Method of Coordination seems to suit the European Union polity better than the Community Method if we compare their features with those of das Schlo $\beta$. The former namely includes more levels, is more in flux with ad hoc procedures and (the associated) effects of policies on structures, adds more governmental and nongovernmental centres to decision-making with more paths between them, and relies more on technocratic consensus. Yet, the Community Method already starts to fit better in das $S c h l o \beta$ when you look closer. Then a more bureaucratic way of doing comes forward, and not just because it would mostly enforce the European Commission as supranational executive and civil service (Walker, 2001). According to Magnette (2000; 2001), the Community Method namely "is a very powerful disincentive for political deliberation, based [as it is] on a long process of informal negotiation and the elaboration of compromise before political discussions take place". Das $S c h l o \beta$ thus even rests in at first sight unbefitting decision-making.

Still, the methods differ significantly. The later Open Method of Coordination departures from the Community Method and state-centric European political integration (Davoudi, 2005a: p. 438). It "has been applied in areas where the [European Union] has no formal competence but in which it is active" (Davoudi, 2005a: p. 438) and/or "where there is a reasonable prospect of Member State agreement" (Schäfer, 2005a: p. 52). Instead of the choice of either formal policy or no policy, this "third way" is then "to be used when harmonisation is unworkable but mutual recognition and the resulting regulatory competition may have unwelcome consequences" (Mosher \& Trubek, 2003: p. 83; Faludi, 2005a: p. 112). The European Commission therefore does not go against its enforcement by the Community Method when it promotes the Open Method of Coordination (CEC, 2001a) for instance. We should thus see both as fitting the institutional fusion and variable geometry of the European Union polity.

What is more, the point here is to understand that the combination of both methods fits das Schlo $\beta$ best. When 
Faludi (2005a: p. 111) wants the Community Method to be supplemented with less top-down and non- legislative instruments, Eriksen (2001) could namely answer that the Open Method of Coordination even complements it thus. Informal compromise can then be made into law by the "hard hand" on the supranational level and/or be enabled by the "soft hand" that, according to Scharpf (2001), supports and strengthens the political legitimacy, institutional integrity, and problem-solving capacity of Member States. The latter also shows the polity as integrative mechanism. It might not come with the harmonisation due to a single policy for all, but "could be an appropriate way to find a common position among Member States" (Schäfer, 2005a: p. 53) to begin with, also by tying centres together; this with suggestions to the European Commission (Schäfer, 2005a: p. 53) and recommendations of it to individual Member States (Scharpf, 2001), which can be supported by evidence from impact assessments (CEC 2001e; Schout et al., 2006: p. 5). Such considerations are thus concerned with core issues of the European Union polity. Now, with this choice in mind, we can therefore start to unfold how the territorial cohesion discourse promoted one method, took the other as fact, but both without treating the political.

\subsection{Using the Political Context for Territorial Cohesion}

In the territorial cohesion discourse the Open Method of Coordination was put forward first. That is, DATAR ${ }^{13}$ proposed this method to reach territorial cohesion as policy objective in 2003 (Faludi, 2004c: p. 1019; Husar, 2006: p. 54). After that also Faludi (2005a: p. 107) presented it thus, even as ideal (Faludi, 2006: p. 28). The method would better cater to the diversity of national welfare systems and "ways of implementing national cohesion and territorial development", especially if regional and local entities are involved (Peyrony, 2007), as Faludi (2005a: p. 114) thinks they should. The complexity involved in the polycentric process would not only reflect the existing diversity, but would also be the price to pay to formulate a European Territorial Cohesion Strategy (Faludi, 2004). In short, the discourse promoted the Open Method of Coordination for territorial cohesion with several reasons.

Not only because it would be (costly) ideal, but also for more pragmatic reasons. To be precise, the Member States" informal process of making the European Spatial Development Perspective, in which also the European Commission took part, would be a perfect basis for it (Faludi, 2004c: p. 1027; Husar, 2006: p. 54). Moreover, the European Spatial Planning Observatory Network (ESPON), a research network, would as the follow up of the European Spatial Development Perspective, with its work on territorial indicators, be its prelude (Faludi, 2006: p. 30). With the funding programme Interreg, with which the European Commission also funds ESPON, these three building blocks can be used to address the territorial dimension of European Union policies (Faludi, 2004c: p. 1028; Husar, 2006: p. 54). This is posed as perfect match due to the commonalities of soft laws, joint responsibility, and mutual learning (Davoudi, 2005a: p. 438-439), such as "[w]orking with guidelines and cooperating through benchmarking, peer reviews and the like" (van Gestel \& Faludi, 2005a: p. 89). That is to say, using the Open Method of Coordination for territorial cohesion would follow the previously existing way of making decisions in European spatial planning nicely.

Yet, at least since the Treaty of Lisbon set territorial cohesion as a European Union objective (OJEC, 2008: p. 127), the Community Method is accepted as a fact in the territorial cohesion discourse. This shared competence namely implies that this method can "at long last" (Faludi, 2005a: p. 111) be applied in territorial cohesion policy, something the European Commission already intended (Faludi, 2006: p. 2) and what the Constitutional's Treaty non-ratification in 2005 might have postponed ${ }^{14}$. There were of course also different political reasons given for this choice instead of the Open Method of Coordination. Besides that the European Commission and Member States viewed the latter negatively (Schmeitz, 2005: p. 403-404), it would according to Briesch ${ }^{15}$ not be enough, and according to an officer from Directorate General Regio ${ }^{16}$ lead to harmonisation of policy, while the Structural Funds approach (e.g. with partnership and territorial cooperation), and perhaps the Community Method therefore, should play a role. In short, the territorial cohesion discourse thus promoted and later accepted the Community Method as well.

\footnotetext{
${ }^{13}$ The influential French institution Délegation à l'Aménagement du Territoire et à l'Action Régionale for territorial "ordering/arrangement" (for the lack of better words) and regional action.

${ }^{14}$ An officer from DG Environment (personal interview in Brussels, 17th of March 2006) suggested this.

${ }^{15}$ Briesch, Representative of the European Economic and Social Committee (Personal notes made by the author present at the CoR's Territorial Dialogue Conference the 1st of March 2006), held so.

${ }^{16}$ An officer from DG Regio (Personal interview in Brussels, 23rd of March 2006) held what is mentioned next and said he therefore disagrees with Faludi on it.
} 
The territorial cohesion discourse therefore harbours some discussion on these methods of decision-making. For us it then does not matter much what these promotions actually entail (e.g. how to stack the building blocks, what is enough, what the approach). The point is, however, that all the reasons mentioned above, either ideal or pragmatic, either for or against a method, show political reasoning instead of reasoning about the political. Although the territorial is, arguably, at least partly political in nature, this does not appear to belong to territorial cohesion itself. Instead, the discourse speaks about the usage of these methods from its political context, even shows how they fit decision-making practices, solely to reach territorial cohesion.

Schmeitz (2005) almost is an exception to this, as he touches upon that what makes these methods political by hinting at the political order in which the Open Method of Coordination for territorial cohesion would function. He starts from that "most international spatial issues are transnational instead of European", and continues that a usage of this method to deal "with the spatial impact of EU policies would simply be ineffective and undesirable because it would add new or shadow structures and procedures to the already complicated EU policy process" (Schmeitz, 2005: p. 403), but then pays no attention these structures and process. The political in itself is thus at most treated indirectly, what leads us to the conclusion that the territorial cohesion discourse does not reason about it.

\subsection{Territorial Cohesion Tricking in das Schlo $\beta$}

You can read in the rest of this essay that an explanation for this appears to be that the territorial cohesion discourse comes from das Schlo $\beta$. In that case the choice between the Community Method and Open Method of Coordination could even be a trick question. As mentioned above, not only do both methods fit the European Union polity, but their combination may fit it best (e.g. as "hard" and "soft hand"). Faludi (2009: p. 22) even points towards something like the Open Method of Coordination for territorial cohesion policy as the way forward while the Community Method applies formally seen, when the European Union does not use the shared competence that is (e.g. due to reasons of administrative overload). Hence, we need to dig deeper into some specificities of the power practices involved (e.g. which?). This also shows that the territorial cohesion discourse comes from das Schlo $\beta$ before the section thereafter explains why this leads to an exclusion of the political.

\section{Showcasing das Schlo $\beta$ with Territorial Cohesion Power Practices}

\subsection{Illustrating Power Practices in the European Union Polity}

We can illustrate das Schlo $\beta$ by sketching the power practices of territorial cohesion in more detail than above, as all the features of the European Union polity return here. Moreover, these specific power practices also exemplify das Schlo $\beta$ by having a role to play in this total system of relations. Before we can address this own role though, we need to have a more detailed understanding of how territorial cohesion shows systematic uncertainty and stands for a battlefield forming a corridor between four areas of action, that is, the Intergovernmental Conferences, European spatial planning, Cohesion policy, and European funding. Each time the ways are therefore presented in which the concepts" usage transforms power relations.

\subsection{Sketching Territorial Cohesion Power Practices ${ }^{17}$}

To enable us to see how territorial cohesion's topical order selectively re/organises institutional spaces with contested positions (e.g. on balance, services, territorial specificities, coordination, the territorial dimension), we first treat the ways in which the concept is used in four areas and thereafter how their linkages form this order. To start with the area in the Intergovernmental Conferences in which it is used. Here a threefold contested usage of the concept appears: 1) for or against a European Union competency for territorial cohesion policy; 2) for or against a European Union competency for spatial planning; and 3) for or against their overlap or relationship. These disputes between, often, Member States with their representatives in the Intergovernmental Conferences therefore act as a filter for how the concept may manifest itself officially (i.e. the in/formality of its usage). With the Lisbon Treaty (CEC, 2008) the first contest was of course decided in favour of a competency for territorial cohesion policy for instance.

The part of the informal area of European spatial planning in which the concept is used, the (post-) European

\footnotetext{
${ }^{17}$ Much of this text comes from the summary of my PhD-thesis (Hissink Muller, 2013).
} 
Spatial Development Perspective usage area, starkly contrasts herewith, as no contested usage of the concept appears here, merely promotions of it do. Territorial cohesion is thereby thus only used by, too simply put, national bureaucrats, often planners, to place a large number of European spatial planning issues on the European agenda. As Bynens \& Van der Lecq (2005: p. 3) position spatial structure on the territorial cohesion agenda as basis for visions to strengthen it by writing this down for example. Due to the amount of such issues they together result in the promotion of European spatial planning with the concept. Yet, by doing so the (post-)European Spatial Development Perspective process does deliver almost all the territorial cohesion content, and therefore informally demarcates the substantive limits for possible usages of said concept (e.g. polycentrism or territorial capital, spatial development or territorial governance).

The Cohesion policy usage area of course demarcates the formal usage of territorial cohesion in European policies. Put too simply again, also bureaucrats of the European Union use the concept. In doing so, this usage promotes the expansion of this formal area of action by combining roaming along the official limits of the concept's usage with cherry-picking from the informal (post-) European Spatial Development Perspective process. This revolves around the questions of what exactly territorial cohesion gives a competency for (e.g. service provision or even policy coordination) and which territorial cohesion content from European spatial planning can be used for Cohesion policy (e.g. polycentrism, informal cooperation). Note that this suggests the anticipation of a competency for territorial cohesion policy before the Lisbon Treaty (OJEC, 2008) came into effect.

The European Funds usage area seems to resonate with the three other usage areas in financial concretisation with a guerrilla-like deployment for territorial cohesion. This resonation is not surprising when you consider that for European funding Member States, their representatives, national bureaucrats and those of the European Union, but also regions, cities, their representatives, and interest organisations act and interact, what also makes it a crowded area of action. With territorial cohesion the European funds might thereby be involved in a messy asymmetrical battle because: 1) the concept's usage appears to be opportunistic; 2) to risk a "schisming" of itself; 3) to risk to become too complex, and this while 4) a channelling of European funds via the concept is contested in fivefold. We will just briefly touch upon these four features, starting with the opportunism of the usage. This is indicated by the multiplicity of interests (e.g. peripheral regions, territorial cooperation) that sometimes return under the concept's flag, which are or are not counterposed, and which were always also promoted without the usage of territorial cohesion. The usage of the concept for these interests might have been nothing more than one of many opportunities to acquire (more) funding, either through an expansion of this area of action, or through a fortification of certain interests within it. The risk of "schisming" then comes from the first formal way in which the concept was used here, namely in the Rural Development Fund in 2006, when it concerns the promotion of territorial balance in their Community strategic guidelines (OJEC, 2006a) to be precise. The resources from this fund are mostly made available for other areas than those for which resources are made available from the more urban Structural Funds, such as the Cohesion and European Regional Development Funds, in which territorial cohesion is also used, as, for example, referred to in Cohesion policy. From the financial point of view the concept then has to endure such a wide split between funding streams that it could schism. The risk of becoming too complex does not come from the increasing variation in interests for which the concept is used, but from the frequently stressed substantive coordination between them, between agricultural and other policies for instance. This makes it more and perhaps too complex. This opportunism, "schisming", and "complexing" also feature in the in fivefold contested channelling of European funds via territorial cohesion. Although this channelling is debated, much namely goes against it: 1) the contests between existing and/or wished for usages of the concept; 2) the in/formality of the positions involved; 3) their guerrilla-like situation; 4) the uncertainty of the concept's influence and 5) that the European Funds usage area seems to play no role in financial affairs. Even though the Intergovernmental Conferences broadened and solidified the formal base for the concept's usage, its financial punching power therefore remains to be seen.

What then makes the concept stand out is its functioning as a three-way crossing between European spatial planning, Cohesion policy, and the European Funds and their fuzzy line of in/formality from the Intergovernmental Conferences. When representatives of particular cities promoted territorial cohesion to get funding for not only their social but also their economic and environmental concerns (e.g. EUROCITIES) ${ }^{18}$ this might have affected bureaucrats of the European Union for instance. How they could have cherry-picked the harmonious relationship between competitiveness and their traditional emphasis on balanced development from European spatial planning for example to reformulate Cohesion policy (e.g. as "window dressing") ${ }^{19}$, as territorial cohe-

${ }^{18}$ Officer from EUROCITIES, personal interview In Brussels, 28 February 2006. 
sion is also deliberated thus by planners, also shown with the "triangle of sustainability" by the Bundesambt für Bauwesen und Raumordnung in the European Spatial Planning Observatory Network (BBR, 2005c: p. 123). Perhaps this specific chain of influence runs the other way around, or has not taken place, but this does not matter to us here. Because any way, even though these interests act in other areas, their usage of the identical concept enables them to take each other's positions (or the counterpositions), due to which territorial cohesion allows for the trans-position of issues, and therefore not only for the interaction between interests, but also the transformation of their areas of action. Two features make this image of a three-way crossing more complicated though: 1) the concept is not only placed between these areas, but also within them of course, and, more challenging; 2) the concept does not only have a location, as it also relocates due to the changing territorial cohesion positions. Luckily we can solve these complications, that is, by seeing the concept itself as a three-way crossing that moves over various power practices.

The way in which territorial cohesion power practices transform power relations is thus by a topical order that selectively re/organises institutional spaces. The concept's usage namely steers towards an indistinct symbiosis of European spatial planning and Cohesion policy due to the usage of the same concept, and thus an overlap of positions. This would subject the former to the latter due to the difference in their in/formal status and the cherry-picking involved. The usage of territorial cohesion on the European level is also accompanied by in/formal "concertedness", as it is unclear who gets a competency for what, and a flexibility in management, as various ways of doing from the different areas of action can be taken up. On the lower levels this could all lead to nebulosity due to the little-known haze that comes from the European Union (e.g. with funding). The usage of territorial cohesion thus reveals implicit but major battles at the margin of the European Union (e.g. on European spatial planning).

\subsection{Recognising das Schlo $\beta$ in Territorial Cohesion Power Practices}

We can now straightforwardly see how territorial cohesion power practices illustrate $d a s$ Schlo $\beta$, whose features also structure our grasp of the systematic uncertainty that characterises this battlefield of many contested positions. These practices namely involve a complex web of concerted interaction over multiple levels (e.g. Member States) and policies (e.g. cohesion and agricultural policy, flexibility in management) which extends beyond the polity's bounds (e.g. informal cooperation, interest organisations), empowers the administration (e.g. spatial planners, cohesion policy officials), and relies on working groups and committees of experts (e.g. the European Spatial Planning Observatory Network). And as the major battles concerned are implicit, all of this also depends more on technical expertise for a technocratic consensus than politics with overt disagreement, including the subterfuge of multi-interpretable policy as shown by the indistinct symbiosis of areas of action and the nebulosity on lower levels on which specific decisions are made. Notwithstanding this clear illustration of features of das $S$ chlo $\beta$ by territorial cohesion power practices, they bring the feature which is not mentioned yet forward most obviously, its flux that is.

The territorial cohesion competency issue then demonstrates the polity working as integrative mechanism in which policies and structures mutually influence each other, what we called the in-built development of das $S c h l o \beta$. The premise thereby is that "[territorial cohesion] has to be integrated into policies in a "multilevel governance" (ESPON, 2005a: p. 32; Husar, 2006: p. 42). This compulsion of the territorial cohesion discourse becomes clear to us with the previously discussed trick question to choose the Community Method or Open Method of Coordination.

What is namely not mentioned there, is that the Open Method of Coordination might also have been promoted because the European Union did not have a shared competency for territorial cohesion (yet), and it could therefore only be reached in other ways; along the path of a competence for coordinating action the European Union already had here for instance (Schäfer, 2005a: p. 52; Schout et al., 2006: p. 12). Such pragmatism might have been opportunistic, as even this method, instead of the informal approach, could move European spatial planning "closer to the European Union level by asking the CEC to coordinate" (Husar, 2006: p. 117). That is to say, the activities of the ministers for spatial development in strengthening territorial cohesion could "be gradually integrated into the formal EU policy process", what not precludes "a need for more intergovernmental co-operation" (Schmeitz, 2005: p. 403-404). "Member states" initiatives aiming at making suggestions for a cross-sectoral coordination strategy for Community policies are not legislative actions under the Community

\footnotetext{
${ }^{19}$ Officer from DG Regio, personal interview in Brussels, 2 March 2006.
} 
method" (Schäfer, 2005a: p. 53) for instance. Territorial cohesion policy therefore comes forward as policy by stealth, whereby territorial cohesion should be reached with whatever method at hand, what influences the political structure due to the continuous transfer of packages of (unclear) tasks to supranational institutions.

Strongly put, territorial cohesion power practices thus demonstrate the decision to go on without making decisions (e.g. in positions, ways of doing, competencies, methods). Illustrative of das Schlo $\beta$ thereby is that due to the many non-decisions and small and unclear decisions the status quo as shown above persists and thus dominates.

\subsection{Exemplifying das Schlo $\beta$ with Territorial Cohesion Power Practices}

Territorial cohesion power practices do more than merely illustrate how das Schlo $\beta$ works and buttressing it though. They also have a more particular role to play in this polity, a role which might be more specific than simply adding to European Union competency, promoting European spatial planning, substantively expanding Cohesion policy, (perhaps) channelling European funding, and linking these areas of action as mentioned above. That they involve multiple policies, beyond just territorial cohesion policy, points to this, as we will find out by considering their role in coordination, for territorial governance, and as testing ground respectively.

An issue high on the agenda of territorial cohesion is coordination. For us it matters less than one time territorial cohesion is said to lead to coordination and the other time that territorial cohesion needs it (Hissink Muller, 2013), as the concept's power practices surely play a role for coordination. The compartmentalized arenas in the European polity, due to the increasing "atomisation" of decision-making (Rometsch \& Wessels, 1996), on the other hand leave "unresolved the larger issue of how eventual conflicts between their decisions are going to be resolved" (Schmitter, 2001). With coordination territorial cohesion therefore goes against a consequence of the polycentric make-up of das Schlo $\beta$, one of its essential features that is Schäfer (2005a: p. 51) for instance says that, because coherence of European Union policies is important to achieve territorial cohesion, the inter-institutional committee recommended in a study for the European Commission on the costs of non-coordination (CEC, 2001e) should include all the institutional bodies directly involved in the Community legislative process. However, as we noted above, such a central body is incapable of controlling this internal co-ordination process (Rometsch \& Wessels, 1996). Instead, or in addition, Guellec's European Parliament's Report on territorial cohesion (EP, 2005c: p. 10) calls for "a better dialogue between the three levels of territorial operators (i.e. Community, national, sub-national) for the consistency between interventions (as set out in the EC's White Paper on governance)". Territorial cohesion policy could thus imply coordination on the European level and/or direct lower levels to do so.

Either way, networking should then decrease the compartmentalisation that comes with polycentricity. Yet, this balancing between features of das Schlo $\beta$ does, with territorial cohesion at least, lead to more "in-transparency" (Rometsch \& Wessels, 1996). The coordination namely relies on technical expertise (e.g. a committee, operators) from multiple levels (e.g. infranationalism) to deal with the substantive complexity involved. With territorial cohesion, a problem of bureaucratic politics (i.e. fragmentation) is then solved with bureaucratic politics (i.e. networking), what, unsurprisingly, leads to more bureaucratic politics, including its problems (i.e. in-transparency).

We should however note that there is no other way for such coordination yet, what makes the role of territorial cohesion power practices potentially larger too. That is to say, in 2001 there was neither an overarching co-ordination model nor did there exist common principles of territorial governance that can serve as a coherent basis for a European polity (Hooghe \& Marks, 2001). Even "after nearly fifteen years of European discussion on what territorial governance is about, there is as yet no established tradition" (Zonneveld, 2007). Territorial cohesion power practices then also play a role for a coherent basis of the polity through territorial governance.

The way they appear to do so moulds territorial governance on the informal practices of European spatial planning; this was touched upon above as well with the latter as basis for reaching territorial cohesion by using the Open Method of Coordination. Zonneveld (2007) even says that the custom is to refer to European spatial planning as territorial governance. This makes it less surprising that Guellec's report (EP, 2005c: p. 10) points for a better dialogue for territorial cohesion towards the European Spatial Development Perspective, which would go "right to the heart of this process of decentralisation, subsidiarity, and governance" ${ }^{20}$. Then again, the making of this perspective was informal. How can informal practices be an example for formal territorial governance as basis for the polity? 
Tewdwr-Jones \&Williams (2001) for starters argue that the impact of European spatial planning "has been almost as significant as that which might have existed if the European Union had been awarded formal spatial planning powers". What is more, it suits well with the usage of "soft law" (Giannakourou, 1996) in the polity, that is, "non-binding recommendations, declarations annexed to treaties and various forms of interpretative communications" rather than essential and formal legislation (Jensen \& Richardson, 2003). In das Schlo $\beta$ “spatial action by a voluntary, cooperative and horizontal model of coordinated European or transnational spatial options and substantive rules by procedural, prospective and general frames of reference and action expressive of information, proposed standards of good practice and recommendations" (Giannakourou, 1996) can namely effectively exist alongside legally enforceable objectives and means of action. The question then is whether this multi-level, polycentric, networking, and technocratic European spatial planning does not only shape the polity's territorial governance, but whether it forebodes the polity's basis as well.

Through territorial cohesion power practices it just might, at least partly. Barnier (2002: p. 202) namely confirmed that "territorial cohesion is a favourite testing ground for novel forms of governance and for concrete applications of subsidiarity" (Faludi, 2003b: p. 134). Yet, it has been the European Union's regional policy that "has transformed the notion of what governance is all about" (Radaelli, 2000: p. 7, p. 9). When you add both together, territorial cohesion power practices come forward as a showcase for combining informal and formal ways of decision-making (i.e. the indistinct symbiosis of European spatial planning and Cohesion policy) ${ }^{21}$. This might be the specific role they play in the polity, especially when they forebode its basis in territorial governance.

Hence, territorial cohesion power practices are not only part of the polity, but play multiple roles in it as well. They thereby also showcase three ways in which public policy can affect political structures towards a deeper integration, the flux of das Schlo $\beta$ that is: 1) bureaucratic coordination; 2) informal but effective territorial governance and 3) combining in/formal ways of doing as basis for the polity. We may also take from this that their illustration, exemplification, and showcasing of the polity's features makes it save to say to that the territorial cohesion discourse comes from das Schlo $\beta$.

\section{Understanding Why Experts Do Not Seem to Know What They Are Talking about}

\subsection{Weaving das Schloß and Territorial Cohesion Expertise}

While the above seems to show that the territorial cohesion discourse comes from das $S c h l o \beta$, the two crucial questions of for what reason this might be the case and why this would lead to an exclusion of the political still remain. Our answer to this hinges on the role that this discourse's expertise plays in the total system of relations. We thereby build forth upon the above-mentioned role of territorial cohesion power practices in the politythese two roles are thus not the same. Do recall that what is hereby endorsed as expertise comes with arbitrary territorial cohesion meanings and knowledge which contradict while they are never reasoned for nor evidenced by tangible facts. Our question then becomes how this questionable system of knowledge relates to the bureaucratic, multi-level, polycentric, and network polity in flux as shown by territorial cohesion power practices.

At the start we already noted that the current conceptualisation of territorial cohesion correlates with the opaque organisation of das Schlo $\beta$, as intellectual positions on it overlap with those taken in its power practices. Just imagine what such a mutual implication can entail when these practices would demonstrate how a polity works by having accepted, clear, and stable positions instead of contested, ambiguous, and variable ones. Arguably, expertise would be steadier grounded then. We can thus realise that territorial cohesion expertise might make actions of das Schlo $\beta$ possible by reasoning in contradictions, such as counterposed actions (e.g. for specific and all regions) with contradicting meanings (e.g. balanced development and coordination). The other way in which the system of territorial cohesion knowledge appears to relate to das Schlo $\beta$, is that this expertise does not seem to allow for explanations of unjustified actions in the polity while promoting them. We address these ways below with the need for expertise in governing complexity and uncertainty and the exclusion of the political by treating governance respectively. Both show that the territorial cohesion discourse divides experts from laymen

\footnotetext{
${ }^{20}$ Eser \& Konstadakopulos (2000: p. 796) also interlink decentralisation (and regionalisation) and spatial planning.

${ }^{21}$ An official from DG Employment and Social Affairs (Personal interview in Brussels, 15th of March 2006) for instance holds that with territorial cohesion DG Regio can mean and/or lead to a different governance model for the European Union (e.g. the Open Method of Coordination).
} 
for technocratic governing and that we can question the expertise of the former not so much due to themselves, but due to the system in which they take part.

\subsection{Governing Complexity and Uncertainty by Territorial Cohesion Expertise}

Why would governing complexity and uncertainty need territorial cohesion expertise? To understand this we must first have in mind what distinguishes expertise from knowledge and power here. Territorial cohesion power practices on the one hand simply show one example of how das Schlo $\beta$ works (e.g. as integrative mechanism) and can be formed (e.g. with effective territorial governance). Deleuze ${ }^{22}$ (2000: p. 121) on the other hand answers the general question "What is knowledge?" abstractly with "the forms of what can be seen and said". We can fill this in for our case as the forms of what territorial cohesion can be seen and said. However, we are more concerned in the ways territorial cohesion knowledge both reassesses the concept's mobilisation of bias (e.g. by reifying institutional reorganisation through description) and informs decision-making (e.g. by devising a European Territorial Cohesion Index). Daily discursive practices (e.g. reasoning) thereby link both, that is, power and knowledge. And this matters for territorial cohesion expertise, as discourse thereby constructs a realm of expertise, and the territorial cohesion discourse thus which texts are considered to be reasonable in this case; this domain is a rule-governed system (Dreyfus \& Rabinow, 1982: p. 24, p. 53), as shown above by the rules of the territorial cohesion discourse that deny/accept texts inside this realm of expertise. Put simply, "experts mediate between the actions of political authorities and the objects-jurisdictions, persons, groups, etc. that fall under their responsibility" (Rose, 1993; Barry et al., 1996: p. 40, p. 50; Uitermark, 2005: p. 146). What kind of pivotal role does territorial cohesion expertise play then?

As territorial cohesion expertise could play a part in $d a s S c h l o \beta$, its role can for starters be characterised by general features of this "play". Then we already see that expertise plays a major role. This decision-making system namely relies strongly on committees of experts (Joerges et al., 1997; Pedler \& Schaefer, 1996; Radaelli, 2000: p. 758), moreover, "governing by persuasion seems to be the most promising way to make European politics work" (Davoudi, 2005a: p. 439). Of course, due to the polity's bureaucratic make-up, we could have expected the high status of experts" discursive practices do note that persuasion might thereby involve rhetoric rather than logic. Yet, the ill-defined limits that come with the polity's polycentric make-up also return here. That is to say, according to Joerges (2001), governance to a large degree builds "on knowledge available not within the administrative machinery but in society" (e.g. committees that are embedded in and supervised by semi-official and private policy networks). Hence, although non-administrative experts might not play a role on stage, behind the scenes they appear to be an essential part of the same play.

This makes it fathomable for us that when Servillo (2010: p. 403) sees territorial cohesion as an inspiring concept open to several interpretations, a "myth" that is, he does not only include political interpretations leading to policy-making but also technical ones from the international debate among stakeholders and scholars. Also the latter's discursive practices then formed it as "catalytic concept around which policy practices have generated discursive chains" with which spatial policies are shaped across Europe (Servillo, 2010: p. 398). What is more, Davoudi (2007) sees the European Spatial Planning Observatory Network (ESPON) as a program and forum for this: "a program of research for identifying best practice and criteria for benchmarking, but also as a forum for deliberation and social learning among researchers and policy makers" (Davoudi, 2007). Then even territorial cohesion researchers thus take part in das $S c h l o \beta$ rather than just researching it. Our question then is what pivotal role territorial cohesion plays in governing complexity and uncertainty.

To answer this question, Roe (1994) helps us by first simply grasping the relations between complexity and uncertainty, but also polarisation, in general terms. ${ }^{23}$ These three are important, because territorial cohesion is one of the many issues plagued by them these days (Hissink Muller, 2013). Often complexity and polarisation thereby cause uncertainty, while "efforts to reduce uncertainty or polarization end up increasing complexity" (Roe, 1994: p. 3). In the particular he for example explains how this works in the San Joaquin Valley. There the complex effects of irrigation (e.g. salinized land) and the polarisation about drainage proposals between agricultural businesses on the one hand and environmentalists and concerned citizens on the other hand (e.g. an ocean pipeline for toxic drain water) has led to uncertainties of how these problems can be tackled in ways that are both technically and politically feasible respectively, while certainty about treatment methods could further

\footnotetext{
${ }^{22}$ Uncertainty as a 'lack of knowledge about what matters', complexity as the 'internal intricacy and/or interdependence of policy issues', and polarisation as the 'concentration of groups around extremes' (Roe, 1994: p. 2).
} 
provoke the antagonists in this controversy (Roe, 1994: p. 87). In the case of territorial cohesion however, a balancing act between complexity and uncertainty seems to avoid conflict, as explained below in abstract terms which follow the specific results on the territorial cohesion discourse shown above.

The choice of risks recognised by Servillo (2010) is then between strategic value and credibility. The attempt to define territorial cohesion in a definite technocratic way could namely lead to the detriment of its strategic role of policy-orientating for European spatial planning, as it becomes less inspiring then (Servillo, 2010: p. 412). Yet, with more intuitive interpretations for strategic reasons, its analytical and scientific value will be lost, as then disciplinary implications might not be specified (Servillo, 2010: p. 412). He even poses that "[a]11 the efforts of the scientific and institutional community, including the ESPON-research programme (ESPON, 2006), can be seen as a response" to this threat to credibility (Servillo, 2010: p. 412). Neither territorial cohesion's uncertainty nor decreasing it are thus an option, while both are needed for the concept to function strategically and credibly respectively. How could this work?

We can only see the action involved in this balancing when we add complexity and polarisation. Uncertainty and complexity thereby reinforce each other. To reduce the lack of knowledge about what matters, research is carried out to enlighten us. Yet, the reduction of uncertainty of where territorial cohesion is about through this research then increases complexity with the knowledge produced (e.g. more issues, relations, details). This complexity in its turn leads to more subjects to review, what increases the uncertainty about which matter for territorial cohesion and how so, what invites more research, leading to a balancing between increasingly more complexity and increasingly more uncertainty. This vicious circle could be broken by simply deciding on where territorial cohesion is about. However, this would entail a polarisation between those for/against this interpretation. In a polity where overt disagreement has no place due to its bureaucratic nature, the degree of complexity must thus be balanced against uncertainty, i.e. strategically enough of it but not incredibly too much to prevent conflict from stopping the show. What is then needed from territorial cohesion expertise to allow for decisionmaking?

To govern the complexity and uncertainty in a technocratic way this expertise is needed to make non-decisions. By producing knowledge that only decreases one by increasing the other (for the vicious circle) to begin with. What for instance can be done by reducing complexity with an abstract overview of possibilities or a description of policy making, such as with discourse coalitions (Waterhout, 2003), or by reducing uncertainty with detailed information about relations between several aspects, such as with a European Territorial Cohesion Index (Hamez, 2005: p. 401). More is asked though. Expertise is namely also needed to perform the balancing act of linking this knowledge and power by discursive practices. And although all these discursive practices together form the discourse, each one also depends on the specific situation; on the perspective, interest, institutional context, and process phase for instance, such as when the Netherlands Environmental Assessment Agency assessed the impact of territorial cohesion for the Netherlands to set priorities that benefit the Dutch government (Evers et al., 2009). When it is thereby added that no aspect of the concept may preclude others (e.g. for consensus), what opens up much room for adding issues, and territorial cohesion is seldom addressed in full (e.g. in theory), what assures that no one has an overview, this creates the conditions for contradictory reasoning (e.g. for conflicting definition-usage relations). In the polity's laboured interactions that lead to policies, expertise's pivotal role is then not so much to provide logically consistent reasons or tangible facts, but to bond contrasting meanings and powers.

Not only does territorial cohesion policy then resemble the patchy- and raggedness of the overall European Union policy picture (Nugent, 1999), but the expertise involved also the "organized anarchy" of the garbage can model (Kingdon, 1995); do note that this model originates from studies on university organisations. No wonder that the language taken up is multi-interpretable (e.g. as subterfuge), since contests must be implied instead of be made explicit. This gives us a different view on the question of how territorial cohesion experts know what they are talking about. It namely seems that they do not know where they are talking about. Moreover, that this is caused by the role they play in the technocratic governing of das Schlo $\beta$. That is, they must avoid conflict (e.g. arguments against a definition) by relating to research that precariously balances the vicious circle of more uncertainty and more complexity of what territorial cohesion is about. When you do not do so, the territorial cohesion discourse excludes you as laymen from its realm of expertise.

\subsection{Excluding the Political by Treating Governance}

Although this role of territorial cohesion expertise in das $S c h l o \beta$ sounds complicating enough, it entails more. 
This comes forward when we consider that territorial cohesion power practices illustrate bureaucratic coordination, exemplify informal but effective territorial governance, and showcase ways to combine in/formal ways of doing as basis for the polity. The polity namely does not only lead to an associated form of expertise, as shown above with its need to govern complexity and uncertainty, this expertise also makes (these) power practices possible, as shown below with two boundaries set up for reasonable territorial cohesion statements.

The particularity of the concept's power practices thereby lays in their systematic uncertainty of unsure changes to always (implicitly) contested points on the agenda. Territorial cohesion expertise of course plays a role in this too, but not only by providing and using contradicting statements. Put simply, besides ensuring that your talk remains vague, always open to be linked with talk from others, and follows European spatial planning and/or Cohesion policy, the discourse's rules namely also exclude a mentioning of politics and theorisation of or reflection on such actions. Our question then is how the expertise obeying these rules safeguards that we do not know what is done in the polity?

Although the discourse does (marginally) treat two methods of decision-making in the polity (i.e. the Community Method and Open Method of Coordination), das Schlo $\beta$ is covered up by not revealing and helping it. That is to say, the power practices are implied but, as shown above, not reasoned over by territorial cohesion expertise. Paradoxically, these practices mostly involve governance and this expertise only speaks of governance. However, to follow Eriksen (2001), "the governance path basically comes down to steering or efficient problem-solving". Salet (2005) therefore differentiates between institution and organisation. Institution would revolve around state and law and democracy, organisation on the other hand around optimisation and coordination/regulation. He thereby places governance studies, just as policy sciences and (nota bene) planning studies, under organisation, and holds that they are then not concerned with justification of public policies or political regimes, but with consensus seeking and border crossing co-production; no wonder Salet (2005) argues that in discourses of governance hierarchical principles are automatically replaced by networking or horizontalism ${ }^{24}$. What then matters to us is that governance and its expertise does not reveal the power practices of decision-making. The territorial cohesion discourse therefore never justifies power practices, making those of the concept itself unjustified as well.

Still, the territorial cohesion discourse does address problems to be solved (instead of decisions to be made) or ways to steer according to already made decisions (i.e. non-decisions). For the practice of the Open Method of Coordination for instance, Faludi (2004c; 2005a: p. 115) would like to see many interpretations of territorial cohesion that serve to improve the understanding of the spatial positions of the actors involved rubbing off on each other. The European Commission "would be thinking of the territory of the European Union as a whole, the administrators of the Member States and the actors forming networks of co-operation in the "petites europe" would be articulating visions of their corners of Europe", all different visions will be valid in their own terms without one being regarded as authorative (Faludi, 2004c; 2005a: p. 115). Such appeasing governance with an undefined territorial cohesion concept helps to ensure that no decision is made. But how does this link to not revealing power practices?

When we simply add both together, we see that the territorial cohesion discourse excludes the political with its treatment of governance, as these both cannot reveal power practices of decision-making and helps to steer according to already made decisions in unjustified practices. We then do not know what happens in das Schlo $\beta$, or at least this part of the polity-the concept's power practices and how they lead to non-decisions, since territorial cohesion expertise treats governance instead of political facts or theory or reflecting on these practices. Do note that this exclusion of the political is an impressive accomplishment, as with the territorial as starting point most people will, arguably, through association automatically think about the political (e.g. decisions on drawing borders). The achievement of this feat (in many ways) both divides territorial cohesion experts from laymen and supports a governing without political decisions.

We then have to wonder why this reason of the territorial cohesion discourse's exclusion of the political lays in that it comes from das Schlo $\beta$. You could now answer that this is the case because the discourse functions as a strategic entity in the in-transparent integrative mechanism formed by the complex and fuzzy web of power

\footnotetext{
${ }^{23}$ To prefer consensus or hierarchy or conflict is a political standpoint. An officer from the Conference of peripheral maritime regions (Personal interview by telephone, 13th of April 2006) for instance holds that the German system with its emphasis on competencies does not exist everywhere, and an administrator of the Committee of the Regions (Personal interview in Brussels, 2nd of February 2006) that partnerships almost run counter to national traditions where political conflict (e.g. Spain, Italy) instead of political consensus (e.g. Northern European countries) is the dominant form.
} 
practices over multiple layers and between multiple centres with lacking political control. It namely appears to beyond balancing complexity and uncertainty by bonding contrasting meanings and powers to avoid conflict and covering up political facts, theory, and reflection by treating governance. The crux is that the discourse then does so whilst it forms the polity with unjustified power practices of bureaucratic coordination, informal and effective territorial governance, and combined in/formal ways of doing as basis and helps it steer according to already made non-decisions. That is to say, the territorial cohesion discourse seems to further das $S c h l o \beta$ without discussion. When the discourse would show the political it could namely lose its strategic value, as this would go against the polity's in-transparency, ill-defined limits, and lacking accountability that allow it to function as it does and instead would clear the way for conflict, enable political control, and ask for justifications. Hence, we may conclude that the polity's actions also lead to and are made possible by territorial cohesion expertise. It namely follows what appears to be a precondition for taking part in the polity, that is, do not discuss das Schlo $\beta$.

\section{Reflectively Concluding on Territorial Cohesion against das Schlo $\beta$}

\subsection{Portraying Territorial Cohesion's Sinister Linkage between Power and Knowledge}

We ponder about the territorial cohesion discourse, as the many territorial cohesion meanings which frame its knowledge correspond to the concept's usages for many issues. Every intellectual choice then implies a political choice. Even more surprising was that experts' discursive practices link these arbitrary, contradicting, never reasoned for nor tangibly evidenced meanings and knowledge to these willful acts in systematically uncertain power practices with always contested agenda points. The four rules that limit what were thereby considered to be reasonable territorial cohesion statements directed our reflection on this estranging situation. These are simply put: do not mention politics, remain rather vague, always be open to link what you say to what others can say, and follow policies of European spatial planning and/or Cohesion policy. At the end, we understand the rather sinister plot, that is, these experts might not know what they are talking about because they play a part for power.

To start with, territorial cohesion's topical order selectively re/organizes institutional spaces with a multitude of contested positions. The concept does so by standing out as a three-way crossing that moves over in/formal power practices. Its usage namely plays a role in adding to European Union competency, promoting European spatial planning, substantively expanding Cohesion policy, and channelling European funding. Territorial cohesion thereby steers towards: 1) an indistinct symbiosis of European spatial planning and Cohesion policy which subjects the former to the latter; 2) an in/formal concertedness on the European level with unclear competencies; 3) a flexibility in management with ways of doing from different areas of action; and 4) a nebulosity on lower levels due to the little-known affairs coming from the European Union. Territorial cohesion policy then comes forward as a multi-interpretable policy by stealth which influences the political structure with continuous transfers of blurred tasks to supranational institutions.

What is more, through political reasoning the discourse even supports the Community Method and/or Open Method of Coordination solely to reach territorial cohesion. It thereby respectively accepts the making of informal compromise into supranational regulation and/or promotes the making of a platform for policy transfer with voluntary cooperation and ad hoc procedures around common policy targets and the naming and shaming that comes with it through monitoring and assessment. Hence, although the discourse does not clarify what should be decided upon, territorial cohesion should thus be reached, either with a hard hand, soft hand, or both. Our point then is that this stronger grip is strangely enough steered and asked for without reasoning about the political itself.

\subsection{Characterising the Polity to Generalise Territorial Cohesion Specifics}

Our explanation for these territorial cohesion specifics lies in the role the discourse seems to play in the political order. We touched upon an essential debate in concurrent political scientific thought for this, as it did treat the European Union's organization, its shaky ground for making collective decisions that is. This contrast also illuminates that the discourse's exclusion of the political cannot only be critiqued because it is illogical, as the territorial arguably is political, and estranging, as its practices and political reasoning push for power, but there was no need for it too, as elsewhere the polity was discussed. There we encountered a Kafkaesque Schlo $\beta$ with mysterious authorities whose opaque government is neither accessible nor explained.

The European Union polity namely always implies multiple levels (e.g. national, regional) which depend on 
each other for authority while they are partly ruled from a centre and rule is also dispersed over them. The thus nested governments thereby give rise to a complex web of continuous negotiation between not only public but also non-public actors which are territorially and functionally differentiated. What is more, the polity is an integrative mechanism as well, because small and detailed packages of competencies are transferred to the supranational level and policies and structures mutually influence each other. As the decision-making centres and rules depend on the issue at stake, such integration leads to networking. This polycentric complex in flux, especially on the meso-level, networks through a bureaucracy which solves problems technically but lacks political control or set priorities. We therefore understood the polity as a multi-layered $S c h l o \beta$ with in-built development which looks like an asymmetrical burr puzzle extending outside its bounds. It thus more resembles a mind-bending lock than a clear-cut castle.

Although most of us would then doubt about what up and down and interior and exterior is, the officials of das Schlo $\beta$ easily run wild in and out inside it, tweaking its working parts, whilst operating as agencies for some and vice versa. What increases the opacity beyond the in-transparency of this varying institutional geometry, are the alike bureaucratic opportunities for evading decisions and rules. The widespread room for manoeuvre through escape routes (e.g. package deals, stealth policy, subterfuge) and windows of opportunity (e.g. institutional reform, shifting institutional context) namely multiplies the already countless and ever changing ways in and in- and outwards the polity. The territorial cohesion discourse then gave us directions for why the reasons given for the actions of those that seem to know the way in this unintelligible $S c h l o \beta$ contradict.

\subsection{Generalising the Role of Territorial Cohesion Expertise through das Schloß}

The discourse does so because its power practices appear to showcase das Schlo $\beta$ and, as the system of territorial cohesion knowledge is associated with them, its form of expertise to belong to it. These power practices indistinct symbiosis namely illustrates the web of the networking bureaucracy of das $S c h l o \beta$, their in/formal concertedness its partly centred and partly dispersed rule in continuous negotiation between differentiated actors, their flexibility in management its room of manoeuvre with decision-making rules depending on the issue at stake, and their nebulosity on lower levels its subterfuge and lacking priorities on and through the meso-level. Moreover, the concept's positions exemplify the polity's ever deeper integration too. Besides through transfers of blurred competencies for territorial cohesion, it's also with three ways in which its policy could affect political structures. This by providing: 1) bureaucratic coordination for a situation which lacks ways to resolve contaminating policies; 2) territorial governance moulded on the informal but effective practices of European spatial planning for a state without it; and 3) a testing ground to combine in/formal ways of doing as basis for the polity while regional policy transformed its governance before. We are therefore confronted with practices that lead to an increasingly complex web of ever more concerted interaction over multiple levels and policies which extend beyond the polity's bounds, empower the administration, and must rely on working groups and committees of experts.

You can understand that battles fought there are implicit when these power practices more depend on technical expertise for a technocratic consensus than on politics with overt disagreement. Together these practices then demonstrate the decision to go on without actually making political decisions. Neither the resulting uncertainty of where territorial cohesion is about nor decreasing it is therefore an option. The former would namely damage the concept's credibility and the latter its strategic functioning. Instead, in this polity the degrees of uncertainty and complexity must be balanced against each other to prevent conflict from stopping the bureaucratic show. It is for governing this uncertainty and complexity in a technocratic way with non-decisions that expertise is needed. We would thus not be surprised when territorial cohesion experts cannot be experts in the sense of knowing where the concept is about. This then simply shows that their discourse comes from das Schlo $\beta$.

This might further mean that rather than researching das $S c h l o \beta$, territorial cohesion experts play an pivotal role in it on stage (e.g. as administrative experts) and behind the scenes (e.g. as scholars). The territorial cohesion discourse namely indicates that its power practices lead to and are made possible by a peculiar expertise. That is to say, it seems to precariously balance the vicious circle of more uncertainty and more complexity of what territorial cohesion is about, bond the concept's contrasting meanings and usages arising in and from specific situations, and cover up the unjustified actions promoted with it. The former is by relating to knowledge that only decreases complexity or uncertainty by increasing the other, with, respectively, an abstract overview or a detailed index for instance. The entailed bonding in specific situations would thereby amount to a contradict- 
ing reasoning on the whole instead of logical consistency or tangible facts. And this territorial cohesion expertise then covers up the concept's power practices by only regarding their governance. Although this covers much of them, governance comes down to steering and governance studies are not concerned with justifying policies or regimes. The discourse could therefore even at first support the Open Method of Coordination with ideal and pragmatic reasons (e.g. better cater to national diversity, follow European spatial planning's way of decisionmaking) and the Community Method later on (e.g. as fact) to reach territorial cohesion. Yet, besides that this formalisation illustrates the polity as integrative mechanism, this backing lacks treatment of the political. As a consequence, we remain ignorant about what is actually happening in the polity when the concept's power practices lead to non-decisions.

You can then see how the territorial cohesion discourse, that is, the combination of the concept's power practices, system of territorial cohesion knowledge, and their relations, functions as a strategic entity in the European Union polity. However, what can we generalise from it? In general the discourse distinguishes experts from laymen and engenders a reliance on the former for an incredible double deed, as they appear to avoid conflict by balancing uncertainty and complexity and the political by treating governance. This ensures that the polity stays in-transparent, its limits ill-defined, and accountability is hard to find instead of clearing the way for conflict, enabling political control, and justifications are called for it. In a nutshell, it looks as if the discourse allows the polity to function as it does. We could thus say that a precondition for all expertise that takes part in $d a s$ Schlo $\beta$ appears to be: keep it quiet.

\subsection{Asking for Territorial Cohesion Counter-Knowledge}

How could we get out of a situation where experts strangely enough do not seem to know what they are talking about because they take part in das Schlo $\beta$ ? From the territorial cohesion discourse two lessons can be learned for this from the polity's flux and inaccessibility and the associated haziness of knowledge and its lacking enlightenment. When expertise balances uncertainty and complexity until exhaustion, it might become too volatile, even in das Schlo $\beta$. The once prominent territorial cohesion can then be discarded for another concept to start all over again. This carousel of expertise would not help to illuminate a blind spot of our knowledge either. While the hierarchies of institution in political theory namely still justify the use of state power (Salet, 2005), the dichotomy between the social and political order has been "inappropriate for the analysis of presents politics and society" for a while now (Jachtenfuchs, 1997: p. 2). These hierarchies then might not accord with social reality anymore even though the specific sphere that would serve res publica instead of gated interests cannot be on an equal footing with private cooperation or social organisation (Salet, 2005). Hence, we do not know how political reality works these days.

I argue that the combined treatment of the territorial cohesion discourse and polity discussion above at least creates some room for a thinking that can enlighten this reality to us. Its double inclusion of the political namely raises new questions on the role of social and spatial science that follow the two lessons mentioned above. First of all due to the recognition that expertise is (also) political. This is not a new point, but seldom followed through. Yet, we could add to Said's (1978) call to widen the field of discussion beyond the limits in accordance with das Schlo $\beta$ that knowledge can be produced against it. The concept of territorial cohesion can for instance be appropriated for another kind of research for this; especially its abandonment would create a window of epistemic opportunity to re-set its research agenda. You could follow up Gualini's (2006) train of thought for example and research how the concept furthers regional interpretations between central governance and decentral differentiation. At large the question in any case is how a social and spatial science that produces knowledge to create conflict plays a role in our society.

Next, the key for opening up das $S c h l o \beta$ is to take a bottom-up perspective. That we take the viewpoint of the governed instead of the governing (e.g. as K. in Kafka's das Schlo $\beta$ ). Only when your point of view is not from the political you can namely include das $S \operatorname{chlo} \beta$ in your sight. In the case of territorial cohesion you then do not look for how to reach it (e.g. which objectives, with what governance), but what of the political world it describes (e.g. which processes, which structures). This could lead to researching the political cohesion between those that govern, or them and those they govern, instead of the social and economic cohesion of the governed. Here the question at large therefore is how social and spatial science can play a role to enlighten how we are governed. Combined these two questions open the way to produce a counter-knowledge that realizes how the political works. This would, at least in the territorial cohesion discourse, enable a new thinking to be heard, following the rallying cry "Knowledge against das Schloß!”. 


\section{References}

AEM, CPMR Islands Commission, EUROMONTANA (undated) Call for the Inclusion of a Territorial Cohesion Objective in the Constitutional Treaty. http://www.constitutional-convention.net/bulletin/archives/000831.html

Amy, D. J. (1984). Why Policy Analysis and Ethics Are Incompatible. Journal of Policy Analysis and Management, 3, 573591.

Ansell, C. K., \& Di Palma, G. (2004). Restructuring Territoriality, Europe and the United States Compared. New York: Cambridge University Press.

Bache, I., \& Flinders, M. (2005). Multi-Level Governance. Oxford: Oxford University Press.

Bachtler, J. \& Polverari, L. (2007). Delivering Territorial Cohesion: European Cohesion Policy and the European Model of Society. In A. Faludi (Ed.), Territorial Cohesion and European Model of Society (pp. 105-128). Cambridge, MA: The Lincoln Institute for Land Policy.

Barnier, M. (2002). Postface. In C. Husson (Ed.), L”Europe sans territoire: Essay sur le concept de cohésion territoriale (pp. 201-203). Paris: DATAR/éditions de l"aube.

Barry, A., Osborne, T., \& Rose, N. (1996). Foucault and Political Reason: Liberalism, Neo-Liberalism and Rationalities of Power. London: UCL Press.

BBR: Bundesambt für Bauwesen und Raumordnung (2005c). ESPON Project 3.1 New Toolds and Instruments for European Spatial Panalysis. Final Report Part C, Integrated Tools for European Spatial Development, July 2005.

Begg, I., Berghman, J., Chassard, Y., Kosonen, P., Madsen, P. K., Matsaganis, M., Mayes, D., Muffels, R., Salais, R., \& Tsakloglou, P. (2001). Social Exclusion and Social Protection in the European Union: Policy Issues and Proposals for the Future Role of the EU. EXSPRO Policy Report, London: European Institute, South Bank University.

Blanco, I., Lowndes, V., \& Pratchett, L. (2011). Policy Networks and Governance Networks: Towards Greater Conceptual Clarity. Political Studies Review, 9, 297-308.

BMVBW: Bundesministerium für Verkehr, Bau und Wohnungswesen (2005). Council of Experts on European Spatial Development, Structure of Spatial Development within the Constitution of Europe-Expert Opinion. Final Report, Berlin: Hunbolds-Universität and Nörr-Stiefenhofer-Lutz Lawyers.

Böhme, K., Richardson, T., Dabinett, G., \& Jensen, O. B. (2004). Values in a Vacuum? Towards an Integrated Multi-Level Analysis of the Governance of European Space. European Planning Studies, 12, 1175-1188.

Brogan, J. V. (1996). A Mirror of Enlightenment: The Rational Choice Debate. Review of Politics, 58, 793-806.

Burchell, G., Gordon, C., \& Miller, P. (1991). The Foucault Effect, Studies in Governmentality, with Two Lectures by and an Interview with Michel Foucault. Chicago: The University of Chicago Press.

Bynens, J., \& Van der Lecq, R. (2005). Connecting Europe to Its Regions: Territorial Cohesion as a Toolkit for an Interwoven Spatial Development Approach, for the AESOP 2005 Vienna Conference, Administration for Spatial Planning of the Ministry of Flanders.

Carporaso, J. A., \& Stone Sweet, A. (2001). Conclusion: Institutional Logics of European Integration Stone Sweet. In W. Sandholtz, \& N. Fligstein (Eds.), The Institutionalization of Europe (pp. 221-236). New York: Oxford University Press.

CEC-Commission of the European Communities (2001a). Unity, Solidarity, Diversity for Europe, Its People and Its Territory. Second Report on Economic and Social Cohesion. Luxembourg: Office for Official publications of the European Communities.

CEC - Commission of the European Communities (2001e). Spatial Impacts of Community Policies and Costs of Non-Coordination. Nederlands: Agence Européenne "Territories and Synergies", EURE-CONSULT, Brussels: Economisch Instituut and Quarternaire Portugal.

CEC-Commission of the European Communities (2004a). A New Partnership for Cohesion Convergence Competitiveness Cooperation, Third Report on Economic and Social Cohesion (p. 107). Luxembourg: COM.

Cowles, M. G., Caporaso, J., \& Risse, T. (2001). Transforming Europe, Europeanization and Domestic Change. Ithaca and London: Cornell University Press.

Davoudi, S. (2005a). Understanding Territorial Cohesion. Planning, Practice \& Research, 20, 433-441.

Davoudi, S. (2006). Evidence-Based Planning. disP: The Planning Review, 42, 14-24.

Davoudi, S. (2007). Territorial Cohesion, European Social Model and Spatial Policy Research. In A. Faludi (Ed.), Territorial Cohesion and European Model of Society (pp. 81-104). Cambridge, MA: The Lincoln Institute for Land Policy.

Deleuze, G. (2000). Foucault. Translated and Edited by Seán Hand, Foreword by Paul Bové, Minneapolis, London: University of Minnesota Press.

Diez, T. (2001). Europe as a Discursive Battleground, Discourse Analysis and European Integration Studies. Cooperation 
and Conflict, 36, 5-38.

Dreyfus, H. L., \& Rabinow, P. (1982). Michel Foucault: Beyond Structuralism and Hermeneutics (2nd Ed.). Chicago, IL: The University of Chicago Press.

Dutch Presidency (2004). Exploiting Europe's Territorial Diversity for Sustainable Economic Growth: Discussion Paper for the EU Informal Ministerial Meeting on Territorial Cohesion. Rotterdam.

Eising, R., \& Kohler-Koch, B. (1999). Governance in the European Union: A Comparative Assessment. In B. Kohler-Koch, $\&$ R. Eising (Eds.), The Transformation of Governance in the European Union(pp.). London: Routledge.

EP-European Parliament (2005c). Report on the Role of Territorial Cohesion in Regional Development. A6-0251/2005, Rapporteur: Ambroise Guellec. Strasbourg: European Parliament.

Eriksen, E. O. (2001). Governance or Democracy? The White Paper on European Governance. In C. Joerges, Y. Meny, \& J. H. H. Weiler (Eds.), Mountain or Molehill? A Critical Appraisal of the Commission White Paper on Governance (p. 408). Brussels: The NYU Institutes on the Park.

Eser, T. W., \& Konstadakopulos, D. (2000). Power Shifts in the European Union? The Case of Spatial Planning, European Spatial Planning, 8, 783-798.

ESPON_European Spatial Planning Observatory Network (2005a). ESPON Project 3.2 -Spatial Scenario's and Orientations in Relation to the ESDP and Cohesion Policy. Second Interim Report, 2004-2006. Luxembourg: ESPON.

www.espon.lu/online/documentation/projects/cross_thematic/cross_thematic_134.html

ESPON_European Spatial Planning Observatory Network (2006). Territory Matters for Competitiveness and Cohesion, ESPON Synthesis Report III. Luxemburg: ESPON.

Evers, D., Tennekes, J., Borsboom, J., Heiligenberg, H., \& van den Thissen, M. (2009). A Territorial Impact Assessment of Territorial Cohesion for the Netherlands. The Hague/Bilthoven: Netherlands Environmental Assessment Agency (PBL).

Faludi, A. (2002b). Positioning European Spatial Planning. European Planning Studies, 10, 897-909.

Faludi, A. (2004b). Territorial Cohesion: Old (French) Wine in New Bottles? Urban Studies, 41, 1349-1367.

Faludi, A. (2004c). The Open Method of Coordination and "Post-Regulatory" Territorial Cohesion Policy. European Planning Studies, 12, 1019-1033.

Faludi, A. (2004e). The European Spatial Development Perspective and North-West Europe: Application and the Future. European Planning Studies, 12, 391-408.

Faludi, A. (2005a). Special Issue of Town Planning Review. 76(1), 2005.

Faludi, A. (2006). From European Spatial Development to Territorial Cohesion Policy. Regional Studies, 40, 667-678.

Faludi, A. (2007). Territorial Cohesion and European Model of Society. t Cambridge, MA: The Lincoln Institute for Land Policy.

Faludi, A. (2009). Territorial Cohesion under the Looking Glass, Synthesis Paper about the History of the Concept and Policy Background to Territorial Cohesion. European Commission Regional Policy-Inforegio, p. 2. http://ec.europa.eu/regional_policy/consultation/terco/pdf/lookingglass.pdf

Faludi, A., \& Waterhout, B. (2002). The Making of the European Spatial Development Perspective-No Masterplan. London/New York: Routledge.

Featherstone, K., \& Radaelli, C. M. (2003). The Politics of Europeanization. New York: Oxford University Press.

Flyvbjerg, B. (2001). Making Social Science Matter, Why Social Inquiry Failed and How It Can Matter Again. Cambridge: Cambridge University Press.

Foucault, M. (1968). Politics and the Study of Discourse. In Burchell, G., Gordon, C., \& Miller, P. (Eds.). (1991)The Foucault Effect, Studies in Governmentality, with Two Lectures by and an Interview with Michel Foucault. Chicago: The University of Chicago Press.

Foucault, M. (1977). Discipline and Punish: The Birth of the Prison. London: Routledge.

Foucault, M. (1978). Governmentality. In G. Burchell, C. Gordon, \& P. Miller (Eds.), The Foucault Effect, Studies in Governmentality, with Two Lectures by and an Interview with Michel Foucault (pp. 87-104). Chicago: The University of Chicago Press.

Foucault, M. (1981). The History of Sexuality: Volume I: An Introduction. Trans. R. Hurley, Harmondsworth: Penguin Books.

Foucault, M. (2006). History of Madness. Translated by J. Murphy and J. Khalfa, Edited by J. Khalfa, London and New York: Routledge.

Giannakourou, G. (1996). Towards a European Spatial Planning Policy: Theoretical Dilemmas and Institutional Implications. European Planning Studies, 4, 595-613. 
Gualini, E. (2006). Van Europa naar de regio en vice versa: multi-level governance en de "Europeanisering" van regional ontwikkelingsbeleid. In L. Janssen-Jansen, \& B. Waterhout (Eds.), Grenzeloze ruimte: Regionale gebiedsgerichte ontwikkelingsplanologie in Europees perspectief. Den Haag: Sdu Uitgevers.

Gualini, E. (2008). "Territorial Cohesion” as a Category of Agency: The Missing Dimension of EU Spatial Policy Debate. European Journal of Spatial Development, 28, 1-22.

Haas, E. (1958). The Uniting of Europe. Stanford: Stanford University Press.

Haas, P. (1992). Introduction: Epistemic Communities and International Policy Coordination. International Organization, 46, 1-35.

Hamez, G. (2005). Territorial Cohesion: How to Operationalise and Measure the Concept? Planning Theory \& Practice, 6, 400-402.

Héritier, A. (2001). The White Paper on European Governance: A Response to Shifting Weights in Interinstitutional Decision-Making. In C. Joerges, Y. Meny, \& J. H. H. Weiler (Eds.), Mountain or Molehill? A Critical Appraisal of the Commission White Paper on Governance. Brussels: The NYU Institutes on the Park. http://www.jeanmonnetprogram.org/archive/papers/01/011301.html

Héritier, A., Knill, C., \& Mingers, S. (1996). Ringing the Changes in Europe: Regulatory Competition and the Transformation of the State, Britain, France, Germany. Berlin: Walter de Gruyter.

Hissink Muller, B. M. (2013). The Place Where Streams Seek Ground, Towards a New Territorial Governmentality: The Meaning and Usage of the Concept of Territorial Cohesion in the European Union. Ipskamp Drukkers: University of Amsterdam.

Hix, S. (1998). The Study of the European Union II: The "New Governance" Agenda and Its Rival. Journal of European Public Policy, 5, 38-65.

Hooghe, L., \& Marks, G. (2001). Multi-Level Governance and European Integration. New York: Lanham, Boulder, Oxford: Rowman \& Littlefield Publishers, Inc.

Hooghe, L., \& Marks, G. (2005). The Neofunctionalists Were (Almost) Right: Politicization and European Integration. Constitutionalism Web-Papers, ConWEB No. 5/2005.

Husar, A. (2006). Towards Territorial Cohesion, the Role of the European Parliament. Master Thesis, Dortmund: University of Dortmund, Faculty of Spatial Planning.

Jachtenfuchs, M. (1997). Democracy and Governance in the European Union. European Integration Online Papers (EIoP), 1, No. 002. http://eiop.or.at/eiop/pdf/1997-002.pdf

Janssen-Jansen, L., \& Waterhout, B. (2006). Grenzeloze ruimte: Regionale gebiedsgerichte ontwikkelingsplanologie in Europees perspectief. Den Haag: Sdu Uitgevers.

Jensen, O. B., \& Richardson, T. (2003). Making European Space, Mobility, Power and Territorial Identity. London and New York: Routledge.

Jessop, B. (2002). The Future of the Capitalist State. Oxford: Blackwell Publishing Ltd.

Joerges, C. (2001). "Economic Order"_-“Technical Realization”-_"The Hour of the Executive": Some Legal Historical Observations on the Commission White Paper on European Governance. In C. Joerges, Y. Meny, \& J. H. H. Weiler (Eds.), Mountain or Molehill? A Critical Appraisal of the Commission White Paper on Governance. Brussels: The NYU Institutes on the Park. http://www.jeanmonnetprogram.org/archive/papers/01/011301.html

Joerges, C., Ladeur, K. H., \& Vos, E. (1997). Integrating Scientific Expertise into Regulatory Decision-Making, National Traditions and European Innovations. Baden-Baden: Nomos.

Kafka, F. (1922/1959). Het Slot, Tweede herziene druk, De Salamander. Amsterdam: Querdio's Uitgeversmij.

Kingdon, J. W. (1995). Agendas, Alternatives, and Public Policies (2nd Ed.). Longman, MI: The University of Michigan.

Kohler-Koch, B. (2001). The Commission White Paper and the Improvement of European Governance. In C. Joerges, Y. Meny, \& J. H. H. Weiler (Eds.), Mountain or Molehill? A Critical Appraisal of the Commission White Paper on Governance. Brussels: The NYU Institutes on the Park. http://www.jeanmonnetprogram.org/archive/papers/01/011301.html

Kohler-Koch, B., \& Eising, R. (1999). The Transformation of Governance in the European Union. London: Routledge.

Le Galès, P. (2002). European Cities, Social Conflicts and Governance. New York: Oxford University Press.

Lukes, S. (1974). Power: A Radical View. London and Basingstoke: The MacMillan Press Ltd.

Magnette, P. (2000). L'Europe, l'Etat et la démocratie. Bruxelles: Complexe.

Magnette, P. (2001). European Governance and Civic Participation: Can the European Union be politicised? In C. Joerges, Y. Meny, \& J. H. H. Weiler (Eds.), Mountain or Molehill? A Critical Appraisal of the Commission White Paper on Go- 
vernance. Brussels: The NYU Institutes on the Park.

http://www.jeanmonnetprogram.org/archive/papers/01/011301.html

Mamadouh, V. (2001). The Territoriality of European Integration and the Territorial Features of the European Union: The First 50 Years. Tijdschrift voor Economische en Sociale Geografie, 92, 420-436.

Marks, G. (1993). Structural Policy and Multilevel Governance in the EC. In A. Cafruny, \& G. Rosenthal (Eds.), The State of the European Community (Volume 2). Harlow: Longman.

Marks, G., Hooghe, L., \& Blank, K. (1996). European Integration from the 1980s: State-Centric v. Multi-Level Governance. Journal of Common Market Studies, 34, 342-378.

Marks, J. (1995). A New Image of Thought. New Formations, 25, 66-76.

Markusen A. (1999). Fuzzy Concepts, Scanty Evidence, Policy Distance: The Case for Rigour and Policy Relevance in Critical Regional Studies. Regional Studies, 33, 869-884.

Martin, R., \& Sunley, P. (2003). Deconstructing Clusters: Chaotic Concept or Policy Panacea? Journal of Economic Geography, 3, 5-35.

Mercier, G. (2005). Which Territorial Cohesion Policy for the New EU Members? The Example of Slovakia, p. 57-68.

Moellers, C. (2001). Policy, Politics or Political Theory. In C. Joerges, Y. Meny, \& J. H. H. Weiler (Eds.), Mountain or Molehill? A Critical Appraisal of the Commission White Paper on Governance. Brussels: The NYU Institutes on the Park. http://www.jeanmonnetprogram.org/archive/papers/01/011301.html

Mosher, J. S., \& Trubek, D. M. (2003). Alternative Approaches to Governance in the EU: EU Social Policy and the European Employment Strategy. Journal of Common Market Studies, 41, 63-88.

Nugent, N. (1999). The Government and Politics of the European Union (4th Edition). Houndmills/Basingstoke/London: Macmillan Press Ltd.

OJEC - Official Journal of the European Communities (2006a). Council Decision of 20 February 2006 on Community Strategic Guidelines for Rural Development (Programming Period 2007-2013), 20606/144/EC.

OJEC - Official Journal of the European Communities (2008). Consolidated Versions of the Treaty of the European Union and the Treaty of the Functioning of the European Union (2008/C 115/01).

Olsen, J. P. (2002). The Many Faces of Europeanization. JMCS, 40, 921-952.

Pawson, R. (2002). Evidence-Based Policy: The Promise of "Realist Synthesis". Evaluation, 8, 340-358.

Pedersen, O. K. (1994). Demokratiets lette tilstand-syv beslutningstagere om Danmark og fremtid (The Lightness of Democracy). Copenhagen: Spektrum.

Pedler, R. H., \& Schaefer, G. F. (1996). Shaping European Law and Policy, the Role of Committees and Comitology in the Political Process. Maastricht: European Institute of Public Administration.

Petzold, W., Guderjan, M., Smeriglio, A., Tourtouri, M., Surubaru, N.-C., Salemink, K., Idczak, P., Kjær Monsson, C., Bajtalan, H., Garau, C., Soultanova, M., Usai, A., Medeiros, E., Szulc, T., Trienes, M., Jaansoo, A., Lange, E., Yalcin, G., Modro, G., \& Venineaux, J.-M. (2015). Future Research on European Union Cohesion Policy: A Master Class during the OPEN DAYS 2014. Regional Studies, Regional Science, 2, 184-203.

Peyrony, J. (2007). Territorial Cohesion and the European Model of Society: French Perspectives. In A. Faludi (Ed.), Territorial Cohesion and European Model of Society (pp. 61-80). Cambridge, MA: The Lincoln Institute for Land Policy.

Radaelli, C. M. (1999). The Public Policy of the European Union: Whither Politics of Expertise? Journal of European Public Policy, 6, 757-774.

Radaelli, C. M. (2000). Whither Europeanization? Concept Stretching and Substantive Change. European Integration Online Papers (EIoP), 4. http://eiop.or.at/eiop/pdf/2000-008.pdf

Roe, E. (1994). Narrative Policy Analysis, Theory and Practice. Durham and London: Duke University Press.

Rometsch, D., \& Wessels, K. (1996). The European Union and Its Member States: Towards Institutional Fusion? Manchester: Manchester University Press.

Roo, G., \& Porter, G. (2007). Fuzzy Planning: The Role of Actors in a Fuzzy Governance Environment. Hampshire: Ashgate Publishing Limited.

Rose, N. (1993). Government, Authority and Expertise in Advanced Liberalism. Economy and Society, 22, 327-399.

Ruggie, J. G. (1993). Territoriality and Beyond: Problematizing Modernity in International Relations. International Organisation, 47, 139-174.

Sabatier, P. (1998). An Advocacy Coalition Framework of Policy Change and the Role of Policy Oriented Learning Therein, Policy Sciences (Vol. 21, pp. 128-168). Boston, Dordrecht, London: Kluwer Academic Publishers.

Said, E.W. (1978/2003). Orientalism. Penguin Books, 1978. 
Salet, W. G. M. (2005). The Myth of Immediacy and the Unbearable Lightness of Governance Discourse. In The AESOP Conference, Vienna, 13-17 July 2005.

Schäfer, N. (2005). Coordination in European Spatial Development, Whose Responsibility? Special Issue of Town Planning Review, 76, 43-56.

Scharpf, F. W. (1999). Governing in Europe, Effective and Democratic? Oxford: Oxford University Press.

Scharpf, F. W. (2000). Notes toward a Theory of Multilevel Governing in Europe. MPlfG Discussion Paper 00/5, Köln: Max-Planck-Institute für Gesellschaftforschung.

Scharpf, F. W. (2001). European Governance: Common Concerns vs. the Challenge of Diversity. In C. Joerges, Y. Meny, \& J. H. H. Weiler (Eds.), Mountain or Molehill? A Critical Appraisal of the Commission White Paper on Governance. Brussels: The NYU Institutes on the Park. http://www.jeanmonnetprogram.org/archive/papers/01/011301.html

Schatschneider, E. E. (1960). The Semi-Sovereign People: A Realist's View of Democracy in America. New York: Holt, Rinehart \& Winston.

Schmeitz, P. (2005). Don't Mention the OMC-Phrase. Planning Theory \& Practice, 6, 400-402.

Schmitter, P. C. (1996). If the Nation-State Were to Whether Away in Europe, What Might Replace It? In S. Gustavsson, \& L. Lewin (Eds.), The Future of the Nation State (pp. 211-244). London: Routledge.

Schmitter, P. C. (2000). How to Democratize the European Union and Why Bother? Lanham: Rowman \& Littlefield Publishers, Inc.

Schmitter, Ph. C. (2001). What Is There to Legitimise in the European Union ... and How Might This Be Accomplished? In C. Joerges, Y. Meny, \& J. H. H. Weiler (Eds.), Mountain or Molehill? A Critical Appraisal of the Commission White Paper on Governance. Brussels: The NYU Institutes on the Park. http://www.jeanmonnetprogram.org/archive/papers/01/011301.html

Schön, P. (2005). Territorial Cohesion in Europe? Planning Theory \& Practice, 6, 389-400.

Schout, S., \& Jordan, A. (2005). Coordinated European Governance: Self Organizing or Centrally Steered? Public Administration, 83, 201-220.

Schout, S., Waterhout, B., \& Jordan, A. (2006). Territorial Policy Integration: A Multilevel Management Perspective, a Draft Working Paper Presented at the Stakeholders Conference Territorial Cohesion and the Lisbon Strategy: Exploiting Europe's Territorial Potentials, 28 June 2006, Amsterdam, Instituut Clingendael, Clingendael European Studies Programme.

Servillo, L. (2010). Territorial Cohesion Discourses: Hegemonic Strategic Concepts in European Spatial Planning. Planning Theory \& Practice, 11, 397-416.

Shore, C. (2000). Building Europe: The Cultural Politics of European Integration. London: Routledge.

Tatzberger, G. (2007). Polycentrism and Territorial Cohesion in the Vienna-Bratislava-Györ Triangle: The European Model of Society in Action. In A. Faludi (Ed.), Territorial Cohesion and European Model of Society (pp. 165-190). Cambridge, MA: The Lincoln Institute for Land Policy.

Tewdwr-Jones, M., \& Williams, R. H. (2001). The European Dimension of British Planning. London: Routledge.

Torgerson, D. (1986). Between Knowledge and Politics: Three Faces of Policy Analysis. Policy Sciences, 19, 33-59.

Uitermark, J. (2005). The Genesis and Evolution of Urban Policy: A Confrontation of Regulationist and Governmentality Approaches. Political Geography, 24, 137-163.

Van Gestel, T., \& Faludi, A. (2005). Towards a European Territorial Cohesion Assessment Network, A Bright Future for ESPON? Special Issue of Town Planning Review, 76, 81-92.

Wæver, O. (1998). Explaining Europe by Decoding Discourses. In A. Wivel (Ed.), Explaining European Integration (pp. 100-146). Copenhagen: Copenhagen Political Studies Press.

Walker, N. (2001) The White Paper in Constitutional Context. In C. Joerges, Y. Meny, \& J. H. H. Weiler (Eds.), Mountain or Molehill? A Critical Appraisal of the Commission White Paper on Governance. Brussels: The NYU Institutes on the Park. http://www.jeanmonnetprogram.org/archive/papers/01/011301.html

Waterhout, B. (2003). Evaluating European Territorial Governance. Paper for the Third Joint ACSP-AESOP Congress 8-12 July 2003 Leuven Belgium. The Netherlands: Delft University of Technology.

Waterhout, B. (2007). Territorial Cohesion: Discourses Underlying. In A. Faludi (Eds.), Territorial Cohesion and European Model of Society (pp. 37-60). Cambridge, MA: The Lincoln Institute for Land Policy.

Weiler, J. H. H. (1999). The Constitution of Europe: “Do the New Clothes Have an Emperor?” and Other Essays on European Integration. Cambridge: Cambridge University Press.

Wessels, W., \& Rometsch, D. (1996). Conclusion: European Union and National Institutions. In D. Rometsch, \& K. Wessels 
(Eds.), The European Union and Its Member States: Towards Institutional Fusion (pp. 328-365). Manchester: Manchester University Press.

Wiehler, F.,\& Stumm, T. (1995). The Powers of Regional and Local Authorities and Their Role in the European Union. European Planning Studies, 3, 227-250.

Williams, R. H. (1996). European Union Spatial Policy and Planning. London: Chapman Publishing.

Wind, M. (2001). The Commission White Paper, Bridging the Gap between the Governed and the Governing? In C. Joerges, Y. Meny, \& J. H. H. Weiler (Eds.), Mountain or Molehill? A Critical Appraisal of the Commission White Paper on Governance. Brussels: The NYU Institutes on the Park. http://www.jeanmonnetprogram.org/archive/papers/01/011301.html

Zito, A. (1998). Epistemic Communities and European Integration. Paper Prepared for the ECPR 26th Joint Sessions of Workshops, Coventry: University of Warwick.

Zonneveld, W. (2007). Unraveling Europe's Spatial Structure through Spatial Visioning: Is There a European Territorial Model of Society? In A. Faludi (Ed.), Territorial Cohesion and European Model of Society (pp. 191-208). Cambridge, MA: The Lincoln Institute for Land Policy.

\section{Submit or recommend next manuscript to SCIRP and we will provide best service for you:}

Accepting pre-submission inquiries through Email, Facebook, Linkedin, Twitter, etc A wide selection of journals (inclusive of 9 subjects, more than 200 journals)

Providing a 24-hour high-quality service

User-friendly online submission system

Fair and swift peer-review system

Efficient typesetting and proofreading procedure

Display of the result of downloads and visits, as well as the number of cited articles

Maximum dissemination of your research work

Submit your manuscript at: http://papersubmission.scirp.org/ 